\title{
Weighing serological evidence of human exposure to animal influenza viruses - a literature review
}

RS Sikkema ${ }^{12}$, GS Freidl ${ }^{12}$, E de Bruin ${ }^{2}, M_{\text {Koopmans }}{ }^{12}$

1. National Institute for Public Health and the Environment (RIVM), Centre for Infectious Diseases Research, Diagnostics and Screening (IDS), Bilthoven, the Netherlands

2. Department of Viroscience, Erasmus MC, Rotterdam, the Netherlands

Correspondence:Reina Saapke Sikkema (r.sikkema@erasmusmc.nl)

Assessing influenza A virus strains circulating in animals and their potential to cross the species barrier and cause human infections is important to improve human influenza surveillance and preparedness. We reviewed studies describing serological evidence of human exposure to animal influenza viruses. Comparing serological data is difficult due to a lack of standardisation in study designs and in laboratory methods used in published reports. Therefore, we designed a scoring system to assess and weigh specificity of obtained serology results in the selected articles. Many studies report reliable evidence of antibodies to swine influenza viruses among persons occupationally exposed to pigs. Most avian influenza studies target $\mathrm{H}_{5}, \mathrm{H}_{7}$ and $\mathrm{H}_{9}$ subtypes and most serological evidence of human exposure to avian influenza viruses is reported for these subtypes. Avian influenza studies receiving a low grade in this review often reported higher seroprevalences in humans compared with studies with a high grade. Official surveillance systems mainly focus on avian $\mathrm{H}_{5}$ and $\mathrm{H}_{7}$ viruses. Swine influenza viruses and avian subtypes other than $\mathrm{H}_{5}$ and $\mathrm{H}_{7}$ (emphasising $\mathrm{H}_{9}$ ) should be additionally included in official surveillance systems. Surveillance efforts should also be directed towards understudied geographical areas, such as Africa and South America.

\section{Introduction}

The family Orthomyxoviridae contains three distinct genera of influenza: A, B and C. Influenza A and B viruses are known to cause high human morbidity and mortality during the yearly seasonal epidemics. In contrast to influenza B viruses, influenza A viruses circulate in many animal species and are able to cross the species barrier, in particular from animal to human. This can occur either directly, or after a unique type of reassortment that results in the generation of viruses that are able to replicate in humans and have haemagglutinin (HA) genes (and less frequently neuraminidase (NA) genes) that are antigenetically distinct from those of seasonal influenza viruses (antigenic shift) [1]. Viruses resulting from 'antigenic shift' have caused four influenza pandemics in the past 100 years: the 'Spanish flu' $A\left(\mathrm{H}_{1} \mathrm{~N}_{1}\right)$ in 1918 , the 'Asian flu' $\mathrm{A}\left(\mathrm{H}_{2} \mathrm{~N}_{2}\right)$ in 1957, the 'Hong Kong flu' $A\left(\mathrm{H}_{3} \mathrm{~N}_{2}\right)$ in 1968, and most recently the $A\left(\mathrm{H}_{1} \mathrm{~N}_{1}\right)$ pdmog pandemic in 2009 [1].

Animal influenza viruses are of concern because of the small but real risk of their adaptation to humans, possibly leading to efficient human-to-human transmission and sustainable circulation in the human population. It has been suggested that rising global trade and travel and changes in human demographics, consumption patterns and behaviours have caused an increase of emerging infectious diseases in general, and zoonotic influenza in particular [2-5]. Well-known examples of animal influenza viruses that have recently infected humans include $A\left(\mathrm{H}_{5} \mathrm{~N}_{1}\right), A\left(\mathrm{H}_{6} \mathrm{~N}_{1}\right), A\left(\mathrm{H}_{7} \mathrm{~N}_{9}\right), A\left(\mathrm{H}_{9} \mathrm{~N}_{2}\right)$ and $A\left(\mathrm{H}_{10 \mathrm{~N} 8)}[6]\right.$.

To improve human influenza surveillance and preparedness, it is important to be able to assess influenza $A$ virus strains circulating in the animal population as to their potential to cross the species barrier and cause human infections. The first step is to collect and review existing scientific studies that assess the prevalence of zoonotic influenza in human populations. Recently, a comprehensive literature review listed published virological evidence for human infection with swine and avian influenza viruses other than $\mathrm{A}\left(\mathrm{H}_{5} \mathrm{~N}_{1}\right)$ [6].

While surveillance based on virologically-confirmed human influenza cases has a high positive predictive value, the approach has some downsides. Virus shedding in infected persons typically lasts only a week and has often diminished or ended by the time of sampling [7]. In addition, infections may cause only mild illness, leading to cases possibly remaining undetected. Studies investigating serological evidence of infection have a wider window of detection and have been used 
to study exposure in human-animal interface settings. A pitfall is that serological data need to be interpreted with caution due to cross-reactivity of antibodies among and within virus subtypes and the problems of sensitivity and reliability of standard serological tests when used to detect antibodies against novel influenza subtypes [8-11].

In this review, we assess studies describing serological evidence of human infection with animal influenza viruses. A scoring system was developed to assess the specificity of the obtained serology results in the selected articles, taking into account both the study design and the laboratory method used. This scoring system was used to weigh the serological evidence for animal influenza exposure in humans. This review can serve as input for an evidence-based risk assessment framework to evaluate novel influenza viruses or variants in light of their potential to create human outbreaks.

\section{Methods}

\section{Search strategy and selection criteria}

We performed a comprehensive literature search for serological studies dealing with zoonotic influenza, using the same search strategy as described in Freidl et al. 2014, but expanding the search period up to February 2014 [6]. The total period covered was from 1946 to February 2014. We additionally conducted a more cursory search to include studies published between February and December 2014.

Two investigators first screened all recovered publications by title and, when necessary, by abstract. They selected reports presenting serological evidence from observational studies describing human infection with animal influenza viruses. Studies of influenza $A\left(\mathrm{H}_{5} \mathrm{~N}_{1}\right)$ were excluded, as serological evidence of $\mathrm{H}_{5} \mathrm{~N}_{1}$ in humans has been extensively reviewed previously $[12,13]$.

The selected studies excluded those describing influenza antibody findings only in animals and those reporting only human-to-human transmission of animal influenza viruses. We also disregarded reviews, commentaries, and articles describing data that were described in previous publications.

\section{Scoring the quality of the evidence}

To be able to assess the value of the outcomes of the selected studies, we developed a scoring system (Table 1, Table 2). For this, we identified important parameters for the evaluation of the specificity of results from observational studies describing serological evidence of human exposure to animal influenza viruses (i.e. study design, laboratory method used, background data on vaccination, exposure data). Subsequently we defined subsets for each parameter, based on review of the literature and Consortium for the Standardization of Influenza Seroepidemiology
(CONSISE) and World Health Organization (WHO) recommendations $[14,15,16]$. Finally we assigned arbitrary points for considered parameters (or subsets thereof) to allow each individual study to be assigned a score; the score of a study was obtained by summing up the points corresponding to the parameters considered in that study. The final scoring system was discussed with virologists and epidemiologists from Erasmus University Medical Center (ErasmusMC) and Oxford University Clinical Research Unit (OUCRU) in Vietnam. The maximum score that a study could obtain was 18 . A detailed breakdown of the scoring system is shown in Table 1. Based on their overall score, we assigned all studies into four categories (A, B, C, D), ranging from best to worst. Category A spanned studies with scores ranging from 15 to 18 points, category B from 10 to 14 points, category $C$ from 5 to 9 points and category $D$ from o to 4 points.

\section{Rationale of the scoring system}

In our scoring system, studies including a control group matched for age (less than 10 years difference in average age), sex (less than 10\% difference in the percentage of women and men) and area (same country) received a higher score (Table 1: 6 of 18), as age, sex and location are possible confounding factors for influenza serology [17-20]. The inclusion of an age-stratified control group is also recommended by the CONSISE [14]. A control group is of particular interest for zoonotic influenza serology, because influenza infections occur repeatedly over a human lifetime, boosting pre-existing antibodies against human influenza viruses which might cross-react with animal influenza virus subtypes [21-26]. Comparison of an animal-exposed study population with a well-defined non-animal-exposed control group is important to avoid over-estimation of the significance of the serological findings. We also assigned a higher score to studies that did not include an agematched control group but did report the age of study participants and corrected their results for age differences, or to studies that stratified their findings in separate age groups.

An antibody titre rise between two samples from the same individual was considered a more reliable measure of infection than obtained by a single serum sample, as individuals served as their own control.

A higher score was assigned to studies which addressed the possibility that antibodies may result from cross-reactivity among influenza subtypes. These studies included vaccination rates and/or tested for human influenza types, both variables known to have an effect on the generation of cross-reactive antibodies $[17,27]$. In order to score all studies in an objective manner, we did not evaluate their analysis of crossreactivity but assigned scores based only on their inclusion of vaccination rate and/or testing for any human influenza type. 
Geographical origin of animal influenza serological studies in humans, 1946-2014 (n=94 studies)
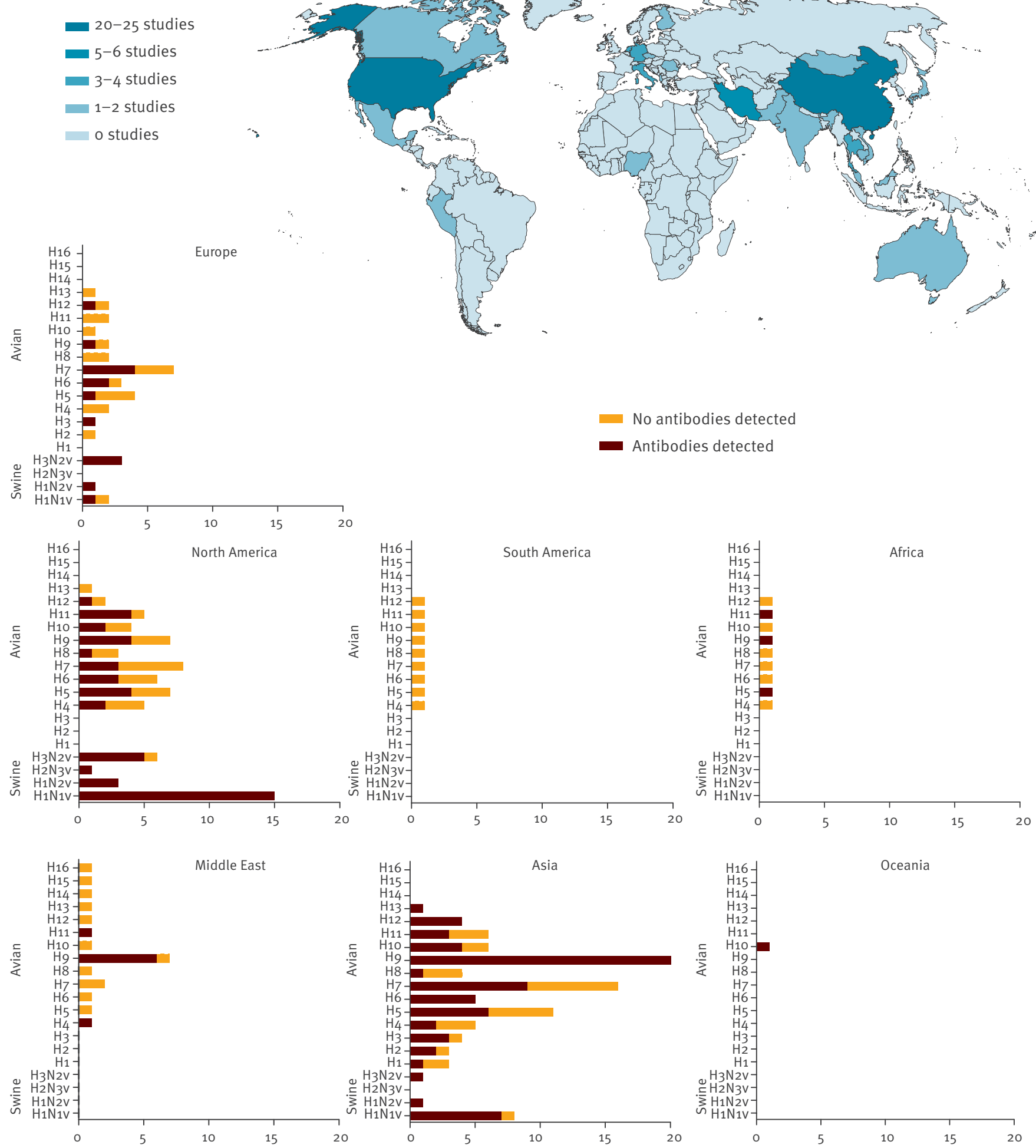

The X-axes of the charts represent the number of publications from that geographical area. The $\mathrm{Y}$ axes show the influenza subtypes.

A higher score was also assigned to studies that added non-serological evidence of exposure of humans, particularly when they provided virological evidence for infection with animal influenza in their human study participants or in the animal population to which the participants had been exposed.
The rationale for our scoring of the laboratory methods used in the studies that we reviewed is based on the official WHO case definitions for human infections with influenza $\mathrm{A}\left(\mathrm{H}_{5} \mathrm{~N}_{1}\right)$ virus [15]. A confirmed case, according to WHO, has a fourfold or greater rise in neutralisation antibody titre or a microneutralisation (MN) 


\section{FIGURE 2}

Diagnostic methods used in serological studies investigating animal influenza exposure of humans according to time period, 1946-2014 ( $\mathrm{n}=94$ studies)

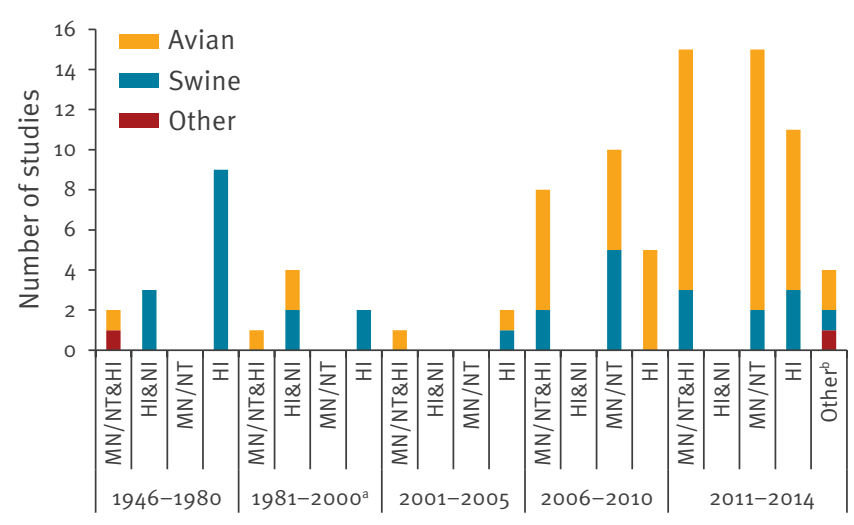

Time period and assay type

HI: haemagglutination inhibition assay; $\mathrm{MN}$ : microneutralisation assay; NI: neuraminidase inhibition assay; NT: neutralisation test.

a One study used single radial analysis.

${ }^{b}$ One study used MN and Western blot as a diagnostic method, two used $\mathrm{HI}$ and enzyme-linked immunosorbent assay (ELISA) and one study used MN and NI assays.

antibody titre of $1: 80$ or greater and a positive result using a different serological assay for example a haemagglutination inhibition ( $\mathrm{HI}$ ) titre of $1: 160$ or greater or a specific Western blot positive result.

Therefore studies that used both $\mathrm{HI}$ and neutralisation assays received the highest scores possible [5] as well as neutralisation assays that were confirmed with Western blot or enzyme-linked immunosorbent assay (ELISA) tests (Table 2). Moreover, studies using a confirmation test scored higher than studies that did not include a second serological assay to confirm their results. A single neutralisation test received three points in part because the WHO considers the MN assay to be the recommended test for measuring antibodies against highly pathogenic avian influenza A viruses. The $M N$ test is an assay with high specificity [28]. The $\mathrm{HI}$ test is also a reliable serological test for influenza antibodies, and studies using this assays therefore receive the second highest score. The NA inhibition (NI) test can play a role in confirmation of influenza A subtypes but is not sufficient as screening test or if used as the only serological assay.

Analysis of the data

All statistical analyses were performed in STATA (StataSE 13.0). For all analyses, a p-value of less than 0.05 was considered statistically significant.

\section{Results}

\section{Search output}

The final output of the literature search was 94 articles $[10,18,19,29-119]$ (Table 3). Some articles could describe more than one study design, animal species, or influenza A subtype. Included were 12 prospective cohort studies, 13 cross-sectional studies in the general population or in rural populations, 57 cross-sectional studies in populations with routine exposure to animals, nine cross-sectional studies in hospital populations, and 11 animal influenza outbreak investigations. We found one report on an investigation of human serological evidence for canine influenza, four studies for equine influenza, 39 for swine influenza, and 56 for avian influenza A. The majority of the studies investigated serological evidence for antibodies to avian subtypes with HA-type $\mathrm{H}_{9}$ (43 articles), $\mathrm{H}_{7}$ (40 articles), $\mathrm{H}_{5}$ (excluding $\mathrm{H}_{5} \mathrm{~N}_{1}, 27$ articles), and swine influenza subtype $\mathrm{H}_{1} \mathrm{~N}_{1}$ variant $\left(\mathrm{H}_{1} \mathrm{~N}_{1} \mathrm{v}\right)$ (36 articles) (Table 3).

Study populations were from Asia $(n=37)$, North America $(n=28)$, Europe $(n=19)$, and the Middle East ( $n=7$, of which 5 were from Iran). For Africa, Oceania and South America, the search yielded only one publication for each. In North America, most studies focused on human infections with swine influenza, whereas in other parts of the world, such as Asia, more emphasis was placed on avian influenza viruses (Figure 1).

In studies investigating swine influenza, the $\mathrm{HI}$ test was used more frequently, while studies that measured human antibodies against avian influenza viruses more often made use of neutralisation tests. Moreover, only studies published in the last decade used neutralisation as single diagnostic test. The use of NI assays on the other hand was only described in one of 72 included articles that were published after 2000, compared with seven of 22 studies that were published in the year 2000 or before (Figure 2 ).

Description of positive cases according to the WHO confirmed case definition could only be extracted from 11 articles [50,55,69,80,87,89,91,99,111,112,115]. These articles used the appropriate diagnostics tests and either reported the antibody titres or used the appropriate cut offs when describing the results.

\section{Scoring the studies}

An overview of the scoring of all studies investigating serological evidence of swine and avian influenza viruses in humans is presented in Figures 2 and 3, respectively. Assuming an arbitrary quality threshold at 9 points (half the maximum score), only $24 \%$ of the studies $(n=23)$ were graded $A$ or $B$, of which only one met the requirements for grade $A$. A total of $57 \%(n=53)$ and $19 \%(n=18)$ of the studies fell into category $C$ and $D$, respectively. All but four grade A and B studies had a control group that was matched for at least two of the three desired characteristics (age, sex and area). 


\section{FIGURE 3}

Scoring results of the included swine and avian influenza serological studies in humans, 1946-2014 ( $\mathrm{n}=94$ studies)

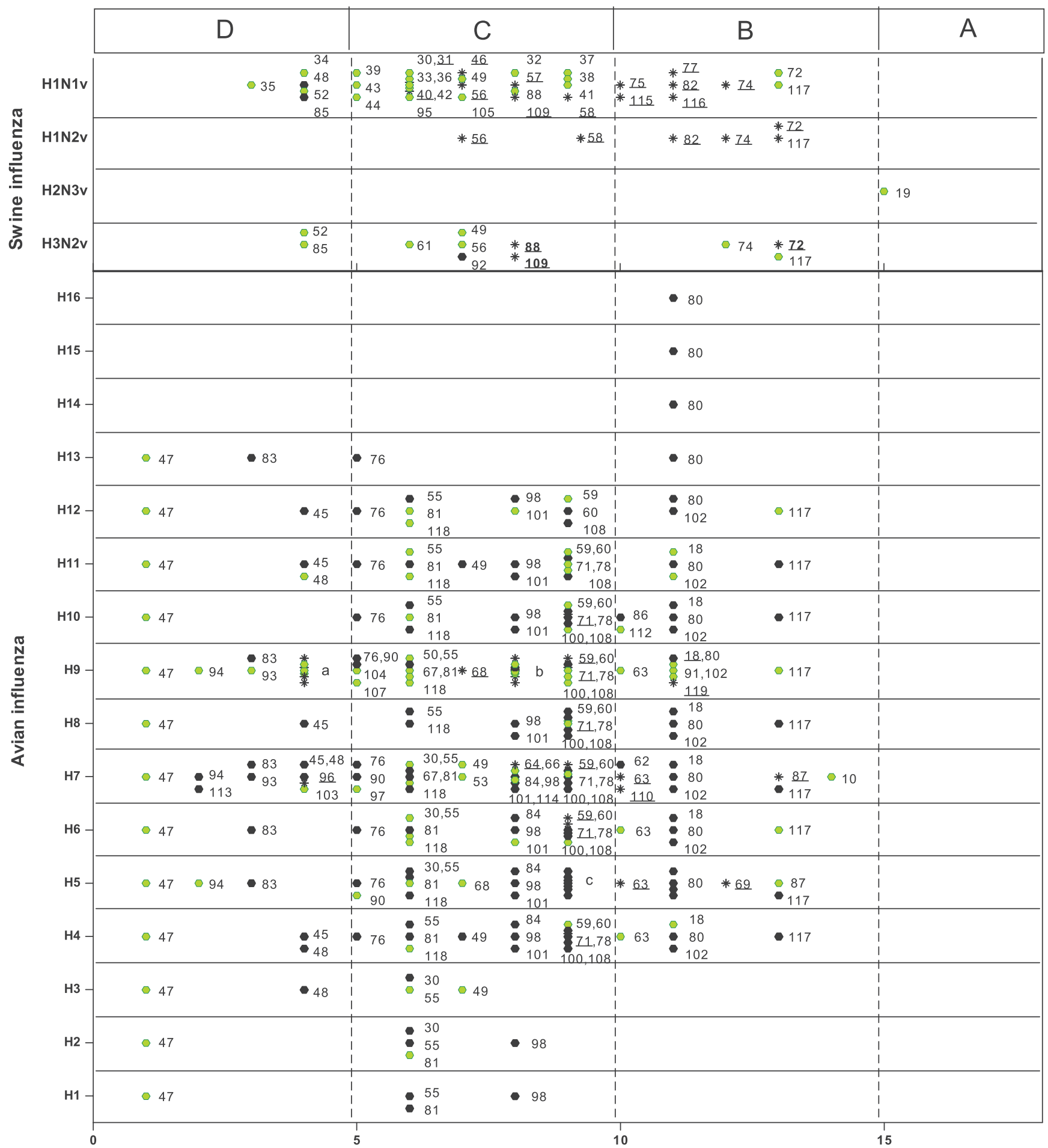

- Antibodies detected with any diagnostic method

- No antibodies detected

* Significant difference between experimental and control group ${ }^{d}$

${ }^{a}$ Reference numbers $51,54,70,73,79,96,103$.

${ }^{\text {b }}$ Reference numbers $64,66,84,89,98,99,101,111,114$.

${ }^{c}$ Reference numbers 59,60,65,71,78,100,108.

${ }^{d}$ Reference numbers of studies with significant difference between experimental and control group are also underlined. 
Such controls were missing or insufficiently matched for most of the grade $C$ studies and all of the grade $D$ studies. The second marked difference was the fact that grade A and B studies more often included a serological confirmation test compared with $C$ and D studies. Of the 23 studies graded A or B, eight investigated serological evidence for swine influenza $\left(\mathrm{H}_{1} \mathrm{~N}_{1} v, \mathrm{H}_{1} \mathrm{~N}_{2}\right.$ variant $\left(\mathrm{H}_{1} \mathrm{~N}_{2} \mathrm{~V}\right), \mathrm{H}_{2} \mathrm{~N}_{3}$ variant $\left(\mathrm{H}_{2} \mathrm{~N}_{3} \mathrm{v}\right)$, and $\mathrm{H}_{3} \mathrm{~N}_{2}$ variant $\left.\left(\mathrm{H}_{3} \mathrm{~N}_{2} \mathrm{v}\right)\right), 14$ pertained to avian influenza viruses $\left(\mathrm{H}_{4}-\right.$ $\mathrm{H} 16)$, and one study investigated human antibodies against a canine influenza virus $\left(\mathrm{H}_{3} \mathrm{~N} 8\right)$. Studies that fell into category $A$ or $B$ were all published relatively recently: category $A$ or $B$ swine influenza studies were all published in 2010 or later, and category A or B avian influenza studies were all published in or after 2006.

\section{Swine influenza}

\section{Cross-sectional studies}

The vast majority of the swine influenza sero-epidemiological studies detected antibodies in a proportion of the population under investigation $(32 / 35$ of studies looking for $\mathrm{H}_{1} \mathrm{~N}_{1} \mathrm{v}$ antibodies, $6 / 6$ for $\mathrm{H}_{1} \mathrm{~N}_{2} \mathrm{~V}$, and 9/11 for $\mathrm{H}_{3} \mathrm{~N}_{2} \mathrm{v}$ ) (Table 3). When single serum samples were analysed, cut-off values of serological assays (HI-assays and neutralisation assays) ranged from 1:10 to $1: 100$. For paired sera, a fourfold titre rise was considered proof of infection, but in cohort studies any titre increase during the study period was reported. The reported seroprevalences differed greatly among studies. In populations occupationally exposed to swine, the prevalence of antibodies to $\mathrm{H}_{1} \mathrm{~N}_{1} \mathrm{v}$ ranged from o\% to almost $80 \%[82,85]$, to $\mathrm{H}_{1} \mathrm{~N}_{2} \mathrm{v}$ from $4 \%$ to $67 \%$ $[72,82]$ and to $\mathrm{H}_{3} \mathrm{~N}_{2} \mathrm{v}$ from $9 \%$ to almost $80 \%[49,72]$. Looking only at the high quality studies (grades $\mathrm{A}$ or $B)$, the reported prevalences were similar to those for $C$ and $D$ studies, with the exception of $\mathrm{H}_{3} \mathrm{~N}_{2} \mathrm{~V}$, for which the highest reported seroprevalence was $28 \%$ [74] (Figure 4). In the unexposed control groups the antibody prevalence to $\mathrm{H}_{1} \mathrm{~N}_{1} \mathrm{v}$ ranged from $0 \%$ to $18.7 \%$ $[31,88]$. One study, published in 1968 , found a seroprevalence to $\mathrm{H}_{1} \mathrm{~N}_{1} \mathrm{v}$ of $67.4 \%$ in the general population, but this could be explained by cross-reacting antibodies against the 1918 pandemic influenza virus in the older population [30]. For $\mathrm{H}_{1} \mathrm{~N}_{2} \mathrm{~V}$ and $\mathrm{H}_{3} \mathrm{~N}_{2} \mathrm{~V}$ the prevalence in the general population and control groups ranged between $1.0 \%$ and $11.4 \%$ and between o\% and $85.0 \%$, respectively $[49,72,74]$.

In studies that investigated the difference between an unexposed control group and the study population (i.e. study participants exposed to animals), a significantly higher number of seropositive people was found in the study population of 13 of 18 of the $\mathrm{H}_{1} \mathrm{~N}_{1} \mathrm{v}$ studies, five of six of the $\mathrm{H}_{1} \mathrm{~N}_{2} \mathrm{v}$ studies, and three of seven of the $\mathrm{H}_{3} \mathrm{~N} 2 \mathrm{v}$ studies.

Cohort studies

Woods et al. and Terebuh et al. found titre increases in antibodies against $\mathrm{H}_{1} \mathrm{~N}_{1} \mathrm{v}$ of $0 \%$ to $8.5 \%$ per year in serum of farm workers and abattoir workers exposed to swine $[43,74]$. Gray et al. found that $25 \%$ of rural residents showed a fourfold increase in antibodies to $\mathrm{H}_{1} \mathrm{~N}_{1}$ v over a two year period from 2004 to 2006 [58]. Slightly lower rates were found for $\mathrm{H}_{1} \mathrm{~N}_{2} \mathrm{v}$, for which $5 \%$ (fourfold antibody titre increase, rural residents) and $8 \%$ (antibody titre rise, farm workers and abattoir workers) of study participants had evidence of exposure over two years $[58,74]$. In the period from 2008 to 2011, both Coman et al. and Gray et al. found a high percentage of seroconversions for $\mathrm{H}_{1} \mathrm{~N}_{1} \mathrm{v}$ and $\mathrm{H}_{1} \mathrm{~N}_{2} \mathrm{~V}$, which were most likely due to cross-reactions with influenza $A\left(\mathrm{H}_{1} \mathrm{~N}_{1}\right)$ pdmog $[117,118]$. Both Coman et al. and Terebuh et al. investigated serological evidence of $\mathrm{H}_{3} \mathrm{~N}_{2} \mathrm{~V}$ exposure during a time-period of two years, concluding that the number of titre increases for different types of $\mathrm{H}_{3} \mathrm{~N}_{2} \mathrm{~V}$ in the swine-exposed group were not significantly higher than in control groups $[74,117]$.

Outbreak studies

The five outbreak studies included in this review targeted people who were exposed to swine infected with $\mathrm{swH}_{1} \mathrm{~N}_{1}(n=4)$ or $\mathrm{swH}_{2} \mathrm{~N}_{3}(n=1)$. Those that investigated people exposed to $\mathrm{swH}_{1} \mathrm{~N}_{1}$ reported seroprevalences ranging from $15 \%$ to $40 \%$ (using various cut-offs), and three of four reported a significant difference between the exposed individuals and a control group $[40,44,46,75]$. All four $\mathrm{H}_{1} \mathrm{~N}_{1}$ v studies were graded $C$, except the study by DaWood et al., which received grade $B$. It reported that $40 \%$ of pig-exposed study participants had a $M N$ titre $\geq 80$ and $\mathrm{HI}$ titre $\geq 20$ [75]. The one study of $\mathrm{H}_{2} \mathrm{~N}_{3} \mathrm{~V}$, graded $\mathrm{A}$, investigated workers who were exposed to $\mathrm{H}_{2} \mathrm{~N}_{3}$-infected swine and found, remarkably, a higher seroprevalence in the unexposed control group [19].

\section{Avian influenza}

\section{Cross-sectional studies}

Most studies screening for antibodies against avian influenza viruses failed to detect antibodies in any proportion of the population under investigation, except for subtype $\mathrm{H} 9$ to which 36 of 43 studies detected antibodies. The cut-off values for neutralisation tests used in the studies ranged from 1:2 to $1: 160$ for $\mathrm{HI}$ and 1:10 to $1: 80$. In the cross-sectional studies over all, antibodies were detected against avian influenza $A$ virus $H A$ subtypes $\mathrm{H}_{1}$ through $\mathrm{H}_{13}$. However, in studies graded A or $\mathrm{B}$, fewer subtypes were detected: $\mathrm{H}_{5}, \mathrm{H}_{6}, \mathrm{H}_{7}, \mathrm{H}_{9}$, $\mathrm{H}_{10}, \mathrm{H}_{11}$ and $\mathrm{H}_{12}$ (Figure 5).

When reviewing only studies that compared prevalence of antibodies in risk groups (subjects in contact with animals) with those from a control group, some studies found significant differences in seroprevalence between both groups for avian influenza subtypes $\mathrm{H}_{4}$ (1 of 14 studies; 1/14), H5 (4/16), H6 (2/13), H7 (6/23), H8 (1/11), H9 (13/29), and H10 (1/12). Insufficient standardisation or description of methods and cut-offs did not allow a direct comparison of the data. 
Seroprevalence of antibodies to different swine influenza viruses in exposed and control humans, 1946-2014 (n=39 studies)

\section{A. Grade A and B}

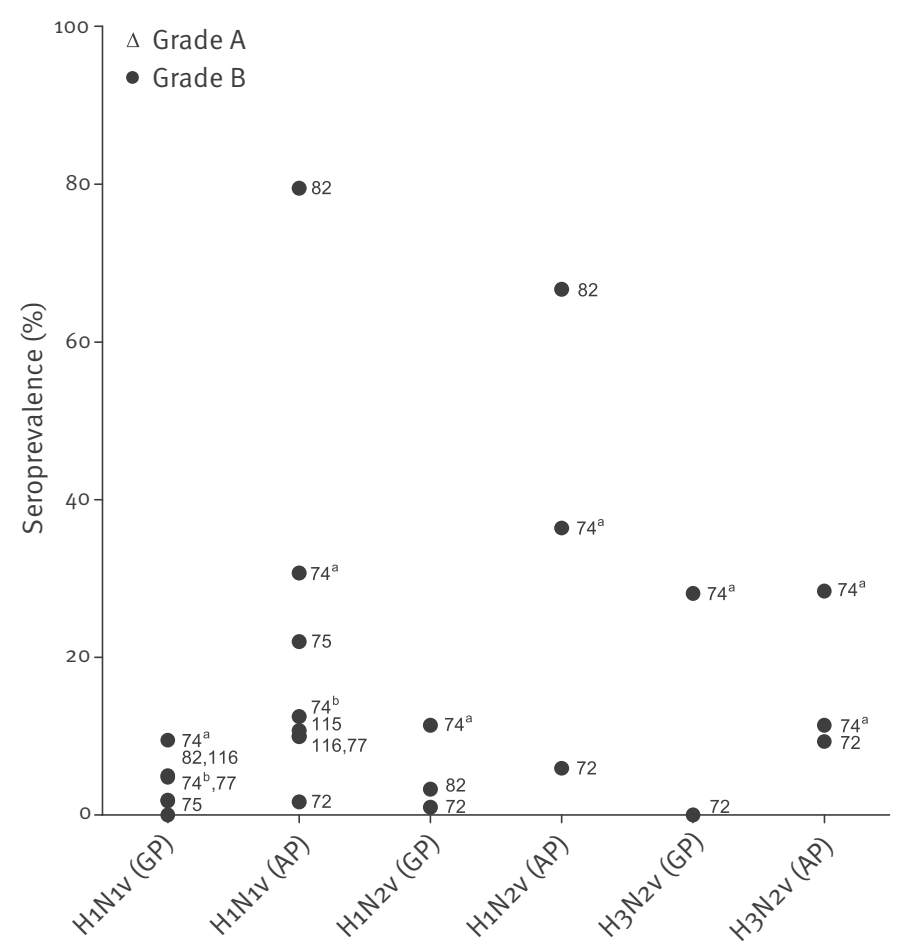

B. Grade C and D

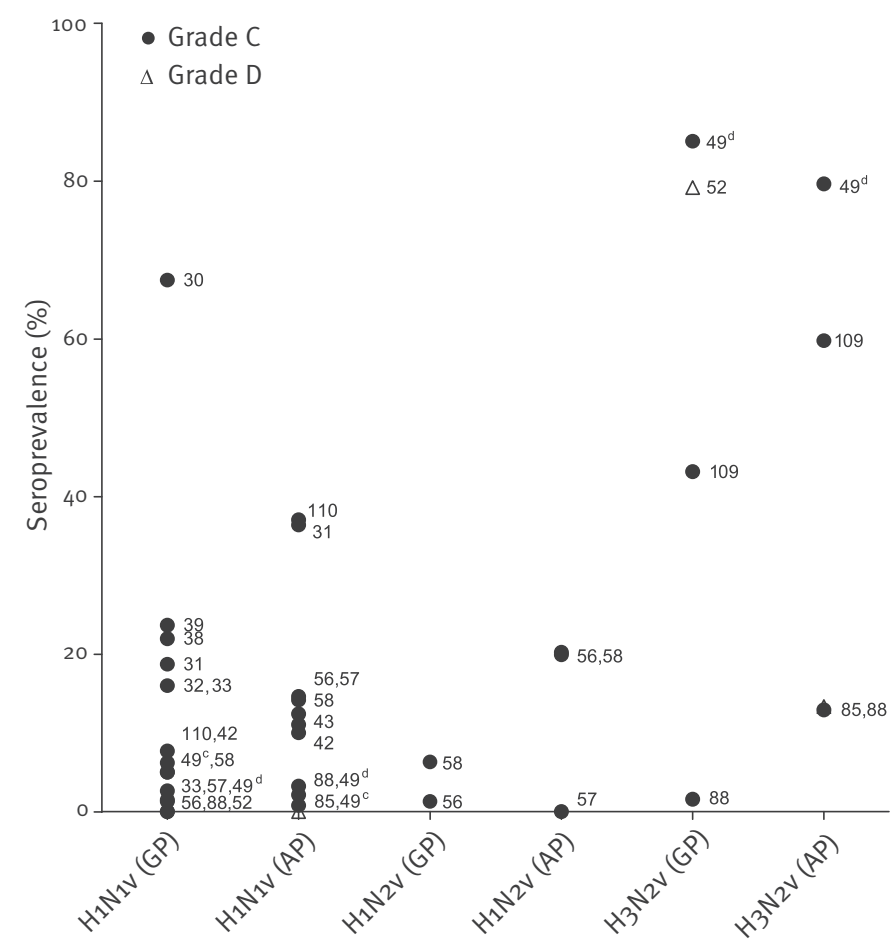

GP: general population or control population; AP: animal-exposed population.

For cohort studies, the seroprevalence at enrolment was included.

${ }^{a} \mathrm{CH}_{1} \mathrm{~N}_{1}$.

${ }^{b} \operatorname{tr} \mathrm{H}_{1} \mathrm{~N}_{1}$.

'Sw/Ita/786/88.

${ }^{d}$ Sw/BJ/47/91.

Studies with a lower score (C or D) appeared to report higher prevalences for avian influenza antibodies than did A or B studies, but the difference was not significant ( $p>0.05)$. Our conclusions were similar when we compared different cut-offs.

Cross-sectional studies: grade A and B studies Most grade $A$ and grade $B$ studies reported serological evidence of $\mathrm{H}_{5}, \mathrm{H}_{7}$ and $\mathrm{H}_{9}$ exposure, but with considerable variation. Gray et al. found a significant difference in the seroprevalence of $\mathrm{H}_{5} \mathrm{~N}_{2}$ antibodies in a swine- and poultry-exposed rural population from lowa, United States, vs unexposed controls from the same region (8.8 vs 0\%) [63]. Okoye et al. found $\mathrm{H}_{5} \mathrm{~N}_{2}$ antibodies in poultry-exposed and -unexposed groups from Nigeria (0.3 vs 1.8\%), however, this difference was not significant $[63,102]$. Moreover, two studies executed in Romania and Vietnam found no antibodies in either group $[18,91]$. Gray et al. also found neutralising antibodies to $\mathrm{H}_{6} \mathrm{~N}_{2}$ and $\mathrm{H}_{7} \mathrm{~N}_{2}$ influenza virus in the same study, but the prevalences were not significantly different between the exposed group and non-exposed controls (1.4 vs $4.0 \%$ and 5.5 vs 0\%) [63]. Five other studies failed to find serological evidence of $\mathrm{H}_{6}$ or $\mathrm{H}_{7}$ exposure $[18,63,80,102,117]$. Only one-cross sectional study looked at $\mathrm{H}_{7} \mathrm{~N} 9$ exposure, finding a seroprevalence of $6.3 \%$ in poultry workers in Guangdong, China, and a significantly lower percentage in non-exposed controls (0\%) [110]. Antibodies to $\mathrm{H}_{9} \mathrm{~N} 2$ avian influenza virus were found in four of seven studies, with seroprevalences ranging from 1.3 to $12.3 \%$ [91,119]. Only Wang et al. found a significantly higher prevalence in exposed vs control persons in Shanghai, China (5.0 vs $1.3 \%$ ). Uyeki et al. included other $\mathrm{H} 9$ antigens and found a low level of antibodies to $\mathrm{H}_{9} \mathrm{~N}_{3}$ and $\mathrm{H}_{9} \mathrm{~N}_{7}$ virus in Vietnamese poultry workers, although the prevalences of $0.5 \%$ and $2.5 \%$, respectively, were not significantly different from the control group (o and 3.5\%) 
Seroprevalence of antibodies to different avian influenza viruses in exposed and control humans 1946-2014 (n=56 studies)

A. Grade A and B

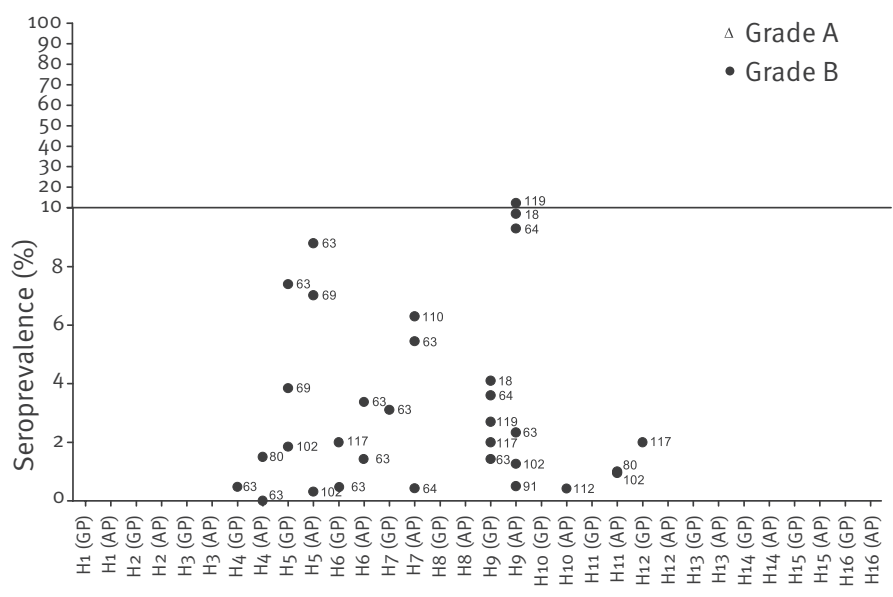

B. Grade C and D

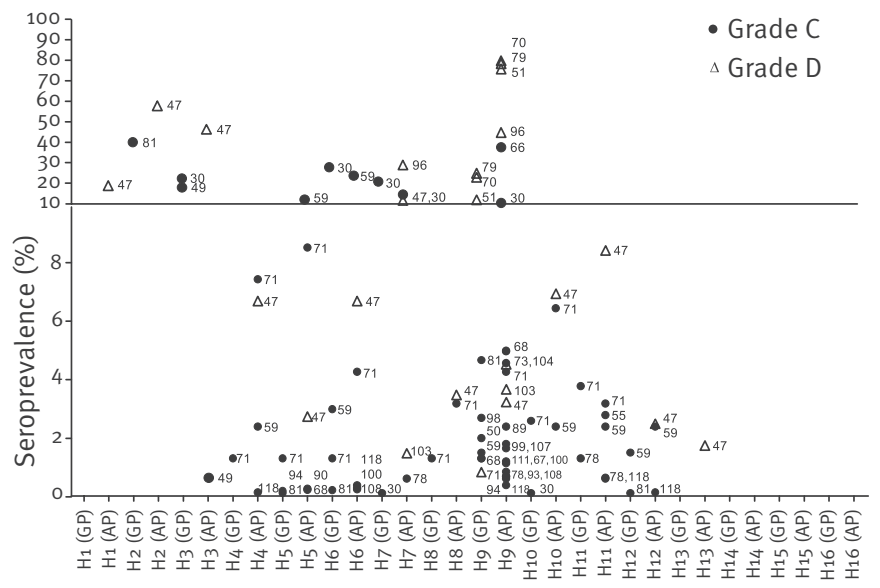

GP: general population or control population; AP: animal-exposed population.

For cohort studies, the seroprevalence at enrolment was included.

[91]. In 2013, Qi et al. found $0.4 \%$ prevalence of antibodies to $\mathrm{H}_{10 \mathrm{~N} 8}$ in animal workers in Guangdong province, China, which did not differ significantly from the non-exposed controls (0\%) [112].

\section{Cohort studies}

A two-year study from Gray et al. in lowa found $0.6 \%$ of swine and poultry unexposed agricultural workers experiencing an antibody increase for $\mathrm{H}_{4} \mathrm{~N} 8$ during this time period, and $0.8 \%$ of exposed and unexposed agricultural workers experiencing an antibody increase for $\mathrm{H}_{5} \mathrm{~N}_{2}$ [63]. Four cohort studies found antibodies to $\mathrm{H}_{6} \mathrm{~N}_{1}$ during their two-year study periods. The percentage of the study populations that experienced an increase in antibody titres ranged between $0.1 \%$ and $2 \%[101,108,117,118]$. Two of the four studies could not find an association with animal exposure. A very low percentage $(<0.3 \%)$ of four of the study populations experienced a slight increase in antibodies against $\mathrm{H}_{4} \mathrm{~N}_{6}, \mathrm{H}_{7} \mathrm{~N}_{7}, \mathrm{H}_{10} \mathrm{~N}_{4}$ or $\mathrm{H}_{12} \mathrm{~N}_{5}[82,101,108,117]$.

Increases in $\mathrm{H}_{9} \mathrm{~N} 2$ antibodies were detected in three two-year cohort studies investigating poultry workers. In Thailand, between 2008 and 2010, $2 \%$ of the study population seroconverted in the first year of the study, and $2.5 \%$ seroconverted in the second year [101]. A similar number of antibody titre increases was found in Mongolia between 2009 and 2011: 2.2\% of the adults experienced an increase in antibodies after either year 1 or year 2 of the study [108]. In both studies there were individuals that showed a fourfold antibody titre increase $(0.3 \%$ and $0.8 \%$ ) but did not report influenzalike illness, suggesting subclinical infections [101,108]. Gray et al. found that $0.3 \%$ of agricultural workers from lowa experienced a titre increase for $\mathrm{H}_{9} \mathrm{~N}_{2}$ during the two-year study period [63].

Besides information about the number of seroconversions, cohort studies provide information on antibody longevity. Lu et al. show that all individuals previously seropositive for $\mathrm{H}_{7} \mathrm{~N}_{7}$ and $\mathrm{H}_{9} \mathrm{~N}_{2}$ sera became seronegative after one year [64]. Krueger et al. likewise found that antibody titres against $\mathrm{H}_{6} \mathrm{~N}_{1}$ and $\mathrm{H}_{7} \mathrm{~N}_{7}$ were undetectable after one year [101].

\section{Outbreak investigations}

The outbreak studies included in this review investigated people who had been exposed to poultry infected with $\mathrm{H}_{5}, \mathrm{H}_{7}, \mathrm{H}_{9}$ or $\mathrm{H}_{10}$. A study of $\mathrm{H}_{5} \mathrm{~N}_{2}$ outbreaks at Japanese chicken farms found a positive $\mathrm{H}_{5} \mathrm{~N}_{2}$ neutralising titre $(M N \geq 1: 40)$ in $25 \%$ of the workers, of whom $7.8 \%$ showed a fourfold antibody increase [65]. Di Trani et al. found that $2.1 \%$ of Italian poultry workers exposed to $\mathrm{H}_{5} \mathrm{~N}_{2}$ - or $\mathrm{H}_{5} \mathrm{~N}_{7}$-infected poultry showed an antibody titre $(H I \geq 1: 10)$, but results were not confirmed by $\mathrm{MN}$, nor was there a significant difference between study participants and unexposed controls [87].

The outbreak studies that found $\mathrm{H}_{7}$ antibodies reported seroprevalences from 0.4 to $3.2 \%$ in exposed poultry workers $[53,87]$. The outbreak study by Di Trani et al. found significantly more antibodies to $\mathrm{H}_{7} \mathrm{~N}_{1}$ and $\mathrm{H}_{7} \mathrm{~N}_{3}$ in $\mathrm{H}_{7}$-exposed poultry workers compared with unexposed controls (3.2 vs 0.8\%) [87]. Another outbreak investigation conducted in Italian poultry workers likewise found $\mathrm{H}_{7} \mathrm{~N}_{1}$ and $\mathrm{H}_{7} \mathrm{~N}_{3}$ antibodies, in $0.4 \%$ and $2.2 \%$ of the workers respectively, but included no controls. Moreover, six of the 983 workers in that study reported conjunctivitis but showed no $\mathrm{H}_{7}$ antibody 
TABLE 1

Scoring system for evaluation of published reports describing seroprevalence studies of zoonotic influenza virus infections

\begin{tabular}{|c|c|c|c|c|c|}
\hline \multirow{2}{*}{ Parameter } & \multirow{2}{*}{$\begin{array}{l}\text { Maximum } \\
\text { score }\end{array}$} & \multicolumn{4}{|c|}{ Individual scores } \\
\hline & & 0 & 1 & 2 & 3 \\
\hline Control group & 6 & No & Unmatched & $\begin{array}{l}\text { Age-matched (2) } \\
\text { Sex-matched (2) } \\
\text { Area-matched (2) }\end{array}$ & NA \\
\hline Repeated sampling ${ }^{b}$ & 2 & No & NA & Yes & NA \\
\hline $\begin{array}{l}\text { Correction for age or } \\
\text { reporting of study } \\
\text { participants' age groups }\end{array}$ & 1 & No & Yes & NA & NA \\
\hline $\begin{array}{l}\text { Human vaccination status } \\
\text { reported }\end{array}$ & 1 & No & Yes & NA & NA \\
\hline $\begin{array}{l}\text { Testing included human } \\
\text { influenza type(s) }\end{array}$ & 1 & No & Yes & NA & NA \\
\hline Other evidence & 3 & No & $\begin{array}{c}\text { Serological evidence in } \\
\text { animals to which humans } \\
\text { were exposed }\end{array}$ & $\begin{array}{l}\text { Virological evidenced in } \\
\text { animals to which humans } \\
\text { were exposed }\end{array}$ & $\begin{array}{l}\text { Virological evidence }{ }^{\mathrm{d}} \text { in } \\
\text { human study participants }\end{array}$ \\
\hline Laboratory method & $\begin{array}{c}5 \\
\text { (Table 2) }\end{array}$ & NA & NA & NA & NA \\
\hline Total & 18 & NA & NA & NA & NA \\
\hline
\end{tabular}

NA: not applicable.

a Two points are added to the final scoring result for age-matched, sex-matched and area-matched controls (same country), adding up to a maximum score of six.

b Sampling to assess changes in antibody levels.

c Score applied only if there was no age-matched control group.

${ }^{d}$ Virus detection by culture or (real-time) reverse transcription-polymerase chain reaction (rtRT-PCR) and sequencing is listed as virological evidence.

response [53]. Using an MN assay with cut-off of $1: 80$, Skowronski et al. found no evidence for human antibody responses in Canadian workers involved in an $\mathrm{H}_{7} \mathrm{~N}_{3}$ outbreak in poultry; but they reported that close contact with the infected poultry correlated with red or watery eyes [62]. In a study of $\mathrm{H}_{7} \mathrm{~N} 7$ by Meijer et al. in the Netherlands, the results from the $\mathrm{HI}$ assay $(\geq 1: 10)$ indicated a prevalence of $49 \%$, but none of the titre rises could be confirmed by $\mathrm{MN}$; however, ocular symptoms of infection appeared more frequently in subjects with $\mathrm{HI}$-detected antibodies compared with subjects without antibodies [10].

One outbreak study investigating H9-exposed poultry farmers found antibodies in 11 of 34 participants (32.3\%), but did not include a control group or describe a cut-off for the HI assay [54]. Arzey et al. investigated abattoir workers exposed to H1oN7-infected poultry and found that two of seven reporting conjunctivitis were polymerase chain reaction (PCR)-positive for influenza $A$; partial sequence analysis of the HA confirmed the presence of $\mathrm{H}_{10}$ subtype, but the findings could not be serologically confirmed [86].

\section{Equine and canine influenza}

Two studies executed before 1970 in Europe investigated human exposure to equine influenza viruses and found prevalences from $4.2 \%$ to $20.9 \%$ for $\mathrm{H}_{3} \mathrm{~N} 8$, using $\mathrm{HI}$ and neutralisation assays, but no non-exposed control group was included $[29,30]$. Khurelbaatar et al. also investigated exposure to equine influenza virus in a Mongolian rural population during a period from 2009 to 2011 and found a seroprevalence of $1.1 \%$ at enrolment. During the two-year follow-up period, $2.5 \%$ of the study population experienced a fourfold titre increase against equine influenza virus $\mathrm{H}_{3} \mathrm{~N} 8$, but exposure to camels or horses was not associated with titres to $\mathrm{H}_{3} \mathrm{~N} 8[100,108]$. Antibody responses have been detected against canine influenza $A\left(\mathrm{H}_{3} \mathrm{~N} 8\right)$ in dog-exposed subjects, but comparison with an unexposed control group yielded no significant difference (20.7 vs $12.1 \%$ ) [106].

\section{Discussion}

There is currently no methodology or tool available for the quality assessment and comparison of influenza serology population studies [120]. In this review we therefore tried to develop a grading system to weigh the evidence for human infection with animal influenza viruses from the included studies. Each attribute of the grading system is either a known confounding factor, and should therefore be included in the analysis or is an accepted method to improve the specificity of the outcome of serological influenza. Although the weights of variables of the scoring system were divided in an arbitrary manner, the scoring system comprises important factors that should be incorporated in future studies investigating human exposure by animal influenza viruses to improve reliability of human serological evidence. 


\section{TABLE 2}

Scores assigned to published studies on zoonotic influenza viruses, according to the initial screening laboratory method used to evidence zoonotic influenza, and the subsequent method for confirmation

\begin{tabular}{|l|l|l|l|l|}
\hline \multirow{2}{*}{ Confirmation method } & \multicolumn{5}{l}{ Screening method } \\
\cline { 2 - 6 } & NT & HI & ELISA & None $^{\text {b }}$ \\
\hline NT $^{\mathrm{a}}$ & NA & 5 & 5 & 3 \\
\hline HI & 5 & NA & 4 & 2 \\
\hline ELISA & 5 & 4 & NA & 2 \\
\hline Western blot & 5 & 4 & 4 & 0 \\
\hline NI & 3 & 3 & 3 & 0 \\
\hline None $^{\text {b }}$ & 3 & 2 & 2 & NA \\
\hline
\end{tabular}

ELISA: enzyme-linked immunosorbent assay; HI: haemagglutination inhibition assay; NA: not applicable; NI: neuraminidase inhibition assay; NT: neutralisation test.

a Neutralisation test: microneutralisation assay or virus neutralisation assay.

${ }^{\mathrm{b}}$ No description of method provided.

It was often not possible to score all aspects of the execution of a study, as details were lacking from its methods section. For example, although we scored for the presence of information on confounding factors, we did not take into account how they were incorporated in the analysis of the data because the methodological information was insufficient to allow this. Nor did we assess the quality and execution of the laboratory tests, because descriptions often omitted details that can very much influence test outcome, e.g. the origin and quality of red blood cells used in HI assays [121].

It is difficult to interpret and compare the diverse antibody titres reported in the literature. Several studies addressing the inter-laboratory variability of influenza $\mathrm{HI}$ and $\mathrm{MN}$ assays have found significant differences in geometric mean $[8,121-124]$. The interpretation of the test results is even more difficult because little is known about the agreement between $\mathrm{HI}$ and $\mathrm{MN}$ assays [122,124]. In addition, pre-existing antibodies against human influenza viruses may cross-react with animal influenza virus subtypes, resulting in titres that are unrelated to exposure or infection with an animal influenza virus [21-23]. Moreover, for many zoonotic influenza A subtypes the optimal detection method is unknown.

In this review, the focus was on assessing the specificity of the reported findings. However, it is possible that clinical or subclinical infections are being missed and that the actual rate of infection is higher than the serological data suggest. For example, individuals exposed to $\mathrm{H}_{7}$ (other than $\mathrm{H}_{7} \mathrm{~N}$ ) have developed a virologically confirmed conjunctivitis when no seroconversion could be detected $[10,62]$. Also, infections with avian influenza causing fever and/or respiratory symptoms can sometimes be confirmed virologically but not serologically $[10,110]$. Moreover, serological responses to zoonotic influenza can wane rapidly, which can lead to underestimation of the frequency of spill-over of animal influenza viruses to humans $[64,125]$.

Different levels of exposure also affect the level of human antibody titres against animal influenza viruses. Some studies compared occupational groups, and many of them find differences in seroprevalence between different occupational groups, which are postulated to reflect differences in exposure $[31,42,43,49,56,62,67,68,70-73,79,93,96,116,117]$. A problem is that influenza infections were rarely measured in the animals to which the study population was exposed at the time of the study, therefore making it difficult to assess the true levels of exposures. The lack of this information may in part explain the seemingly contrasting conclusions reached regarding the occupational groups that have the highest seroprevalence to animal influenza: some studies find the highest antibody titres in veterinarians $[43,72]$ while others find the highest titres in farmers $[56,70]$, abattoir workers [31] or poultry market workers [68]. Moreover, the term 'occupational exposure', as well as different occupational groups are loosely defined, which makes them very hard to compare. Ahad et al. for example found high titres of avian influenza antibodies in poultry vaccinators, but very few other studies have looked at poultry vaccinators as a separate group occupationally exposed to poultry [96].

Looking at the studies collected for this review, it becomes clear there is no agreement on the diagnostic methods, cut-offs or study design that should be used to investigate the prevalence of zoonotic influenza in humans. This limits both the interpretation and the comparability of the available data. Following the $\mathrm{H}_{1} \mathrm{~N}_{1}$ pandemic in 2009, the WHO reached the same conclusions in a review on the pandemic and requested standardised methods to improve the comparability of the serological data [125]. Although the CONSISE published recommendations and protocols to standardise serological studies on zoonotic influenza virus outbreaks, human influenza virus epidemics, and seasonal influenza, there are no guidelines for the design and execution of population studies for influenza on the human-animal interface $[126,127]$.

An interesting finding is that studies graded $C$ or $D$ in this review generally reported higher seroprevalences to avian influenza viruses in humans than A or B studies. It is possible that using a less stringent study protocol leads to an overestimation of serological findings of animal influenza in humans. Therefore, to increase the reliability of the evidence and reduce the occurrence of false positive outcomes, inclusion of confounding factors either in the study design or the data analysis is important.

In this review we see that antibodies to swine influenza viruses $A\left(H_{1} N_{1}\right) v, A\left(H_{1} N_{2}\right) v$, and $A\left(H_{3} N_{2}\right) v$ are more prevalent among persons occupationally exposed to pigs compared with those not exposed. However, given 
TABLE 3

Results of literature search on zoonotic influenza viruses, 1946-2014 ( $\mathrm{n}=94$ publications)

\begin{tabular}{|c|c|c|c|c|c|}
\hline $\begin{array}{l}\text { Influenza } \\
\text { virus }\end{array}$ & $\begin{array}{l}\text { Influenza } \\
\text { subtype }\end{array}$ & $\begin{array}{l}\text { Number } \\
\text { of studies } \\
\text { included }^{\mathrm{a}}\end{array}$ & $\begin{array}{l}\text { Laboratory methods used } \\
\text { (number of studies) }\end{array}$ & $\begin{array}{l}\text { Number of studies detecting } \\
\text { antibodies in study group } \\
\text { (proportion of included studies) }\end{array}$ & $\begin{array}{c}\text { Number of studies detecting significant difference with control group } \\
\text { (studies detecting significant difference with control group/total } \\
\text { number of studies with control group) }\end{array}$ \\
\hline Canine & $\mathrm{H}_{3} \mathrm{~N} 8$ & 1 & MN/NT and NI (1) & $1(1 / 1)$ & $\mathrm{o}(\mathrm{o} / 1)$ \\
\hline \multirow{2}{*}{ Equine } & $\mathrm{H}_{3} \mathrm{~N} 8$ & 4 & $\begin{array}{c}\mathrm{MN} / \mathrm{NT} \text { and } \mathrm{HI}(2) \\
\text { MN/NT (2) }\end{array}$ & $4(4 / 4)$ & $0(0 / 2)$ \\
\hline & $\mathrm{H}_{7} \mathrm{~N}_{7}$ & 2 & MN/NT and $\mathrm{HI}$ (2) & $0(0 / 2)$ & $\mathrm{o}(\mathrm{o} / \mathrm{o})$ \\
\hline \multirow{4}{*}{ Swine } & $\mathrm{H}_{1} \mathrm{~N}_{1 \mathrm{~V}}$ & 35 & $\begin{array}{c}\text { MN/NT and HI (3) } \\
\text { HI and NI (6) } \\
\text { HI (22) } \\
\text { MN/NT (3) } \\
\text { ELISA (1) }\end{array}$ & $32(32 / 35)$ & $13(13 / 20)$ \\
\hline & $\mathrm{H}_{1} \mathrm{~N}_{2} \mathrm{~V}$ & 6 & $\begin{array}{c}\text { MN/NT and } \mathrm{HI}(1) \\
\text { HI (5) }\end{array}$ & $6(6 / 6)$ & $5(5 / 6)$ \\
\hline & $\mathrm{H}_{2} \mathrm{~N}_{3} \mathrm{~V}$ & 1 & MN/NT and $\mathrm{HI}(1)$ & $1(1 / 1)$ & $\mathrm{o}(0 / 1)$ \\
\hline & $\mathrm{H}_{3} \mathrm{~N}_{2} \mathrm{~V}$ & 11 & $\begin{array}{c}\text { MN/NT and HI (2) } \\
\text { HI and NI (1) } \\
\text { HI (7) } \\
\text { ELISA (1) }\end{array}$ & $9(9 / 11)$ & $3(3 / 7)$ \\
\hline \multirow{16}{*}{ Avian } & $\mathrm{H}_{1}$ & 4 & $\begin{array}{l}\text { MN/NT and } \mathrm{HI}(1) \\
\text { MN/NT (2) } \\
\text { Single radial analysis (1) }\end{array}$ & $1(1 / 4)$ & $0(0 / 1)$ \\
\hline & $\mathrm{H}_{2}$ & 5 & $\begin{array}{l}\mathrm{MN} / \mathrm{NT} \text { and } \mathrm{HI}(2) \\
\text { MN/NT (2) } \\
\text { Single radial analysis (1) }\end{array}$ & $2(2 / 5)$ & $0(0 / 1)$ \\
\hline & $\mathrm{H}_{3}$ & 5 & $\begin{array}{l}\mathrm{MN} / \mathrm{NT} \text { and } \mathrm{HI}(2) \\
\mathrm{HI} \text { and NI (2) } \\
\text { Single radial analysis (1) }\end{array}$ & $3(3 / 5)$ & $0(0 / 1)$ \\
\hline & $\mathrm{H}_{4}$ & 22 & $\begin{array}{c}\mathrm{MN} / \mathrm{NT} \text { and } \mathrm{HI}(2) \\
\mathrm{HI} \text { and NI (3) } \\
\text { MN/NT (15) } \\
\mathrm{HI}(1) \\
\text { Single radial analysis (1) }\end{array}$ & $6(6 / 22)$ & $1(1 / 14)$ \\
\hline & $\begin{array}{c}\mathrm{H}_{5} \\
\text { (not } \mathrm{H}_{5} \mathrm{~N}_{1} \text { ) }\end{array}$ & 27 & $\begin{array}{c}\text { MN/NT and HI (5) } \\
\text { MN/NT and Western blot (1) } \\
\text { MN/NT (18) } \\
\text { HI (2) } \\
\text { Single radial analysis (1) }\end{array}$ & $12(12 / 27)$ & $4(4 / 16)$ \\
\hline & $\mathrm{H} 6$ & 21 & $\begin{array}{c}\text { MN/NT and HI (3) } \\
\text { MN/NT (15) } \\
\text { HI (2) } \\
\text { Single radial analysis (1) }\end{array}$ & $12(12 / 21)$ & $2(2 / 13)$ \\
\hline & $\mathrm{H}_{7}$ & 40 & $\begin{array}{c}\text { MN/NT and HI (10) } \\
\text { HI and NI (3) } \\
\text { MN/NT (17) } \\
\text { HI (9) } \\
\text { Single radial analysis (1) }\end{array}$ & $16(16 / 40)$ & $6(6 / 23)$ \\
\hline & $\mathrm{H} 8$ & 16 & $\begin{array}{c}\text { MN/NT and HI (2) } \\
\text { HI and NI (1) } \\
\text { MN/NT (12) } \\
\text { Single radial analysis (1) }\end{array}$ & $2(2 / 16)$ & $1(1 / 11)$ \\
\hline & $\mathrm{H}_{9}$ & 43 & $\begin{array}{c}\text { MN/NT and HI (10) } \\
\text { MN/NT and Western blot (1) } \\
\text { HI and ELISA (1) } \\
\text { MN/NT (17) } \\
\text { HI (13) } \\
\text { Single radial analysis (1) }\end{array}$ & $37(36 / 43)$ & $13(13 / 29)$ \\
\hline & $\mathrm{H}_{10}$ & 19 & $\begin{array}{c}\text { MN/NT and HI (3) } \\
\text { MN/NT (13) } \\
\text { HI (2) } \\
\text { Single radial analysis (1) }\end{array}$ & $6(6 / 19)$ & $1(1 / 12)$ \\
\hline & $\mathrm{H}_{11}$ & 19 & $\begin{array}{c}\text { MN/NT and HI (2) } \\
\text { HI and NI (3) } \\
\text { MN/NT (12) } \\
\text { HI (1) } \\
\text { Single radial analysis (1) }\end{array}$ & $9(9 / 19)$ & $0(0 / 11)$ \\
\hline & $\mathrm{H}_{12}$ & 14 & $\begin{array}{c}\text { MN/NT and } \mathrm{HI}(2) \\
\text { HI and NI (1) } \\
\text { MN/NT (9) } \\
\text { HI (1) } \\
\text { Single radial analysis (1) }\end{array}$ & $5(5 / 14)$ & $0(0 / 7)$ \\
\hline & $\mathrm{H}_{13}$ & 4 & $\begin{array}{c}\mathrm{MN} \text { and } \mathrm{HI}(2) \\
\mathrm{HI}(2)\end{array}$ & $1(1 / 4)$ & $0(0 / 1)$ \\
\hline & $\mathrm{H}_{14}$ & 1 & $\mathrm{MN}$ and $\mathrm{HI}(1)$ & $\mathrm{o}(0 / 1)$ & $\mathrm{o}(\mathrm{o} / 1)$ \\
\hline & $\mathrm{H}_{15}$ & 1 & $\mathrm{MN}$ and $\mathrm{HI}(1)$ & $\mathrm{o}(0 / 1)$ & $\mathrm{o}(0 / 1)$ \\
\hline & $\mathrm{H}_{16}$ & 1 & $\mathrm{MN}$ and $\mathrm{HI}(1)$ & o (o/1) & $\mathrm{o}(0 / 1)$ \\
\hline
\end{tabular}

ELISA: enzyme-linked immunosorbent assay; HI: haemagglutination inhibition assay; MN: microneutralisation assay; NI: neuraminidase inhibition assay; NT: neutralisation test.

a A given article could describe more than one study design, animal species, or influenza A subtype, so the total number of studies in this column is greater than 94 .

${ }^{b}$ More detailed information can be found in the supplementary table (http://www.erasmusmc.nl/viroscience/research/suppl-table-animal-influenza-human-serology. pdf/?view=active)

' Studies in which a significant difference was explicitly mentioned or for which a significant difference could be calculated based on the data provided. 
the potential for cross-reactivity within subtype, serological studies that investigate human infection with swine influenza should be interpreted with great caution. Unlike avian influenza viruses, endemic swine influenza viruses often have common origins with seasonal human influenza viruses. Novel pandemic influenza human viruses have originated from swine viruses or have been introduced in swine, and play an important role in the evolution of genetic diversity of swine influenza viruses [128]. For instance, with the recent emergence of pandemic $\left(\mathrm{H}_{1} \mathrm{~N}_{1}\right) 2009$ virus and subsequent reintroductions in the swine population, serological population studies investigating human infection with swine influenza viruses should be designed and interpreted with extreme caution to differentiate true exposures from cross-reactions [129,130]. Nevertheless, the number of studies finding a significant difference in seroprevalence between swineexposed study groups and unexposed control groups is strong evidence of frequent spill-over events from swine to humans. The high number of reported swineto-human transmissions and evidence for subsequent human-to-human transmission, in combination with the recent emergence of pandemic $\left(\mathrm{H}_{1} \mathrm{~N}_{1}\right) 2009$ virus, warrants increased serological and virological surveillance of swine and people that are exposed to swine $[6,131]$. Unfortunately swine influenza surveillance is less prevalent than avian influenza surveillance, and there is relatively little knowledge on prevalence and circulation of swine influenza [132].

According to our assessment, the most reliable serological evidence (grade A and B) was found for human exposure to avian influenza virus $\mathrm{HA}$-types $\mathrm{H}_{5}, \mathrm{H}_{7}$, and $\mathrm{H}$. The risk of infection with $\mathrm{H}_{5}$ and $\mathrm{H}_{7}$ subtypes is illustrated by the serious recent outbreaks of subtypes $\left(\mathrm{H}_{5} \mathrm{~N}_{1}\right)$ virus and $\mathrm{A}\left(\mathrm{H}_{7} \mathrm{~N}_{9}\right)$ virus in humans, which, as of late 2016, have resulted in 452 and 320 deaths, respectively [133]. Few cases of humans infected with avian $\mathrm{H} 9$ viruses have been reported: Freidl et al. described in their literature review the virological evidence of 15 cases of humans infected with $\mathrm{H}_{9} \mathrm{~N}_{2}$ [6]. However, avian $\mathrm{H}_{9} \mathrm{~N}_{2}$ viruses are a growing concern, and the mild disease associated with $\mathrm{H}$ 9 infection potentially leads to considerable underestimation of incidence $[50,134,135]$. H9 avian influenza can be found in poultry all over the world and is also described in multiple other avian species, pigs and dogs [136-139]. Moreover, internal genes of $\mathrm{A}\left(\mathrm{H}_{9} \mathrm{~N}_{2}\right)$ were found in $\mathrm{A}\left(\mathrm{H}_{1} \mathrm{ON} 8\right), \mathrm{A}\left(\mathrm{H}_{7} \mathrm{~N}_{9}\right)$ and $\mathrm{A}\left(\mathrm{H}_{5} \mathrm{~N}_{1}\right)$, showing that $\mathrm{A}\left(\mathrm{H}_{9} \mathrm{~N}_{2}\right)$ can reassort with other influenza subtypes, potentially resulting in the generation of new zoonotic influenza types [140-142]. In 2013, human cases of infection with $\mathrm{H} 10 \mathrm{~N} 8$ and $\mathrm{H} 6 \mathrm{~N} 1$ were reported, as well as presence of these serotypes in environmental samples from animal markets, showing that $\mathrm{H} 6$ and $\mathrm{H}_{10}$ serotypes can likewise pose a risk to human health [140,143-145]. Serological cohort studies of persons exposed to poultry provide information on the incidence and longevity of antibodies to zoonotic influenza viruses. For most avian influenza subtypes, this information is currently unknown and will greatly contribute to the risk analysis of zoonotic avian influenza.

Although human antibodies have been found against equine and canine influenza, these infections seem to be a minor public health risk. However, the very limited number of studies could lead to substantial under-reporting.

\section{Conclusion}

Comparing human serological data is difficult due to a lack of standardisation in the collection of epidemiological data and the laboratory methods used in published zoonotic influenza studies. Researchers should take into account WHO guidelines, known confounding factors and the need for a control group in order to produce research articles that can be used and compared by policymakers and other researchers to better assess the risks and prevalence of animal influenza exposure in humans.

Swine-to-human transmission is prevalent, but national surveillance systems and standard serological surveillance of swine and human risk groups is scarce. Surveillance for avian influenza is more common, but most veterinary surveillance systems target $\mathrm{H}_{5}$ and $\mathrm{H}_{7}$ serotypes and, accordingly, most serological evidence is reported for these subtypes. Given the zoonotic potential of avian influenza viruses, which can potentially reassort with circulating seasonal human influenza virus subtypes, systematic surveillance in poultry populations should be expanded beyond $\mathrm{H}_{5}$ and $\mathrm{H}_{7}$, the primary focus for the veterinary sector $[146,147]$. Subtypes $\mathrm{H}_{6}, \mathrm{H}_{9}$ and $\mathrm{H}_{10}$ are known to be able to infect humans and should therefore be included. Moreover, structured surveillance of human risk groups to detect spill over of influenza viruses is rare and should be implemented in national surveillance systems. Finally, we found that the majority of studies conducted at the human-animal interface represent Asia, Europe, and North America. Efforts should be made to shed light on understudied areas, such as South America and Africa.

\section{Conflict of interest}

None declared.

\section{Authors' contributions}

Reina Sikkema: literature search, study design, data analysis, data interpretation, writing; Gudrun Freidl: literature search, study design, data interpretation; Erwin de Bruin: study design, data interpretation; Marion Koopmans: study design, data interpretation.

\section{References}

1. Cox NJ, Subbarao K. Global epidemiology of influenza: past and present.Annu Rev Med. 2000;51(1):407-21. DOI: 10.1146/ annurev.med.51.1.407 PMID: 10774473

2. Cleaveland S, Haydon DT, Taylor L. Overviews of pathogen emergence: which pathogens emerge, when and why?Curr Top Microbiol Immunol. 2007;315:85-111. DOI: 10.1007/978-3-54070962-6_5 PMID: 17848062 
3. Kuiken T, Fouchier R, Rimmelzwaan G, Osterhaus A. Emerging viral infections in a rapidly changing world. Curr Opin Biotechnol. 2003;14(6):641-6. DOI: 10.1016/j. copbio.2003.10.010 PMID: 14662395

4. Reperant LA. Applying the theory of island biogeography to emerging pathogens: toward predicting the sources of future emerging zoonotic and vector-borne diseases.Vector Borne Zoonotic Dis. 2010;10(2):105-10. DOI: 10.1089/vbz.2008.0208 PMID: 19589061

5. Kuiken T, Holmes EC, McCauley J, Rimmelzwaan GF, Williams CS, Grenfell BT. Host species barriers to influenza virus infections.Science. 2006;312(5772):394-7. DOI: 10.1126 science.1122818 PMID: 16627737

6. Freidl GS, Meijer A, de Bruin E, de Nardi M, Munoz O, Capua I, et al. , FLURISK Consortium. Influenza at the animal-human interface: a review of the literature for virological evidence of human infection with swine or avian influenza viruses other than $\mathrm{A}\left(\mathrm{H}_{5} \mathrm{~N}_{1}\right)$. Euro Surveill. 2014;19(18):20793. DOI: 10.2807/1560-7917.ES2014.19.18.20793 PMID: 24832117

7. Carrat F, Vergu E, Ferguson NM, Lemaitre M, Cauchemez S, Leach $\mathrm{S}$, et al. Time lines of infection and disease in human influenza: a review of volunteer challenge studies. Am J Epidemiol. 2008;167(7):775-85. DOI: 10.1093/aje/kwm375 PMID: 18230677

8. Stephenson I, Das RG, Wood JM, Katz JM. Comparison of neutralising antibody assays for detection of antibody to influenza $\mathrm{A} / \mathrm{H}_{3} \mathrm{~N}_{2}$ viruses: an international collaborative study.Vaccine. 2007;25(20):4056-63. DOI: 10.1016/j. vaccine.2007.02.039 PMID: 17412461

9. Wood JM, Gaines-Das RE, Taylor J, Chakraverty P. Comparison of influenza serological techniques by international collaborative study.Vaccine. 1994;12(2):167-74. DOI: 10.1016/0264-410X(94)90056-6 PMID: 8147099

10. Meijer A, Bosman A, van de Kamp EE, Wilbrink B, van Beest Holle MDR, Koopmans M. Measurement of antibodies to avian influenza virus $\mathrm{A}\left(\mathrm{H}_{7} \mathrm{~N}_{7}\right)$ in humans by hemagglutination inhibition test.J Virol Methods. 2006;132(1-2):113-20. DOI: 10.1016/j.jviromet.2005.10.001 PMID: 16271401

11. Wibawa H, Henning J, Waluyati DE, Usman TB, Lowther S, Bingham J, et al. Comparison of serological assays for detecting antibodies in ducks exposed to $\mathrm{H}_{5}$ subtype avian influenza virus. BMC Vet Res. 2012;8(1):117. DOI: 10.1186/17466148-8-117 PMID: 22823985

12. Wang TT, Parides MK, Palese P. Seroevidence for $\mathrm{H}_{5} \mathrm{~N}_{1}$ influenza infections in humans: meta-analysis. Science. 2012;335(6075):1463. DOI: 10.1126/science.1218888 PMID: 22362880

13. Van Kerkhove MD. Brief literature review for the WHO global influenza research agenda--highly pathogenic avian influenza $\mathrm{H}_{5} \mathrm{~N}_{1}$ risk in humans. Influenza Other Respi Viruses. 2013;7(Suppl 2):26-33. DOI: 10.1111/irv.12077 PMID: 24034480

14. Consortium for the Standardization of Influenza Seroepidemiology (CONSISE). Investigation of Zoonotic Respiratory Infection in Humans Exposed to a Confirmed Source. CONSISE; 2013. Available from: https://consise.tghn. org

15. World Health Organization (WHO). WHO case definitions for human infections with influenza $A\left(\mathrm{H}_{5} \mathrm{~N}_{1}\right)$ virus. Geneva: WHO; 2006. Available from: http://www.who.int/influenza/ resources/documents/case_definition2006_08_29/en/

16. World Health Organization (WHO). Recommendations and laboratory procedures for detection of avian influenza $A\left(\mathrm{H}_{5} \mathrm{~N}_{1}\right)$ virus in specimens from suspected human cases. Geneva: WHO; 2007. Available from: http://www.who.int/influenza/ resources/documents/RecAllabtestsAug07.pdf

17. Hancock K, Veguilla V, Lu X, Zhong W, Butler EN, Sun H, et al. Cross-reactive antibody responses to the 2009 pandemic H1N1 influenza virus. N Engl J Med. 2009;361(20):1945-52. DOI: 10.1056/NEJMoa0906453 PMID: 19745214

18. Coman A, Maftei DN, Krueger WS, Heil GL, Friary JA, Chereches $\mathrm{RM}$, et al. Serological evidence for avian $\mathrm{H}_{9} \mathrm{~N}_{2}$ influenza virus infections among Romanian agriculture workers. J Infect Public Health. 2013;6(6):438-47. DOI: 10.1016/j.jiph.2013.05.003 PMID: 23999337

19. Beaudoin A, Gramer M, Gray GC, Capuano A, Setterquist S, Bender J. Serologic survey of swine workers for exposure to $\mathrm{H}_{2} \mathrm{~N}_{3}$ swine influenza A.Influenza Other Respi Viruses. 2010;4(3):163-70. DOI: 10.1111/j.1750-2659.2009.00127.x PMID: 20409213

20. World Health Organization (WHO). Sex, gender and influenza in achieving gender equality and health equity. Geneva: WHO; 2010. Available from: http://apps.who.int/iris/ bitstream/10665/44401/1/9789241500111_eng.pdf

21. Corti D, Suguitan AL, Pinna D, Silacci C, Fernandez-Rodriguez BM, Vanzetta F, et al. Heterosubtypic neutralizing antibodies are produced by individuals immunized with a seasonal influenza vaccine. J Clin Invest. 2010;120(5):1663-73. DOI: 10.1172/JCl41902 PMID: 20389023

22. Oshansky CM, Wong SS, Jeevan T, Smallwood HS, Webby RJ, Shafir SC, et al. Seasonal influenza vaccination is the strongest correlate of cross-reactive antibody responses in migratory bird handlers. MBio. 2014;5(6):e02107. DOI: 10.1128/ mBio.02107-14 PMID: 25491354

23. Corti D, Voss J, Gamblin SJ, Codoni G, zMacagno A, Jarrossay $D$, et al. A neutralizing antibody selected from plasma cells that binds to group 1 and group 2 influenza $A$ hemagglutinins. Science. 2011;333(6044):850-6. DOI: 10.1126/science.1205669 PMID: 21798894

24. Roozendaal R, Tolboom J, Roos A, Riahi S, Theeuwsen J, Bujny MV, et al. Transient humoral protection against $\mathrm{H}_{5} \mathrm{~N}_{1}$ challenge after seasonal influenza vaccination of humans. PLoS One. 2014;9(7):e103550. DOI: 10.1371/journal. pone.0103550 PMID: 25075622

25. Gioia C, Castilletti C, Tempestilli M, Piacentini P, Bordi L, Chiappini R, et al. Cross-subtype immunity against avian influenza in persons recently vaccinated for influenza. Emerg Infect Dis. 2008;14(1):121-8. DOI: 10.3201/eid1401.061283 PMID: 18258091

26. Sui J, Sheehan J, Hwang WC, Bankston LA, Burchett SK, Huang $C Y$, et al. Wide prevalence of heterosubtypic broadly neutralizing human anti-influenza A antibodies. Clin Infect Dis. 2011;52(8):1003-9. DOI: 10.1093/cid/cir121 PMID: 21460314

27. Lynch GW, Selleck P, Church WB, Sullivan IS. Seasoned adaptive antibody immunity for highly pathogenic pandemic influenza in humans.Immunol Cell Biol. 2012;90(2):149-58. DOI: $10.1038 /$ icb.2011.38 PMID: 21647170

28. World Health Organization (WHO) Global Influenza Surveillance Network. 2.G. Serological diagnosis of influenza by microneutralization assay. Part 2. The laboratory diagnosis and virological surveillance of influenza. In: Manual for the laboratory diagnosis and virological surveillance of influenza. Geneva: WHO; 2011. ISBN 9789241548090.

29. Masurel N, Mulder J. Studies on the content of antibodies for equine influenza viruses in human sera.Bull World Health Organ. 1966;34(6):885-93.PMID: 5296537

30. Tümová B, Svandová E, Stumpa G. Findings of antibodies to animal influenza viruses in human sera and their significance for the study of interviral antigenic relationship.J Hyg Epidemiol Microbiol Immunol. 1968;12(3):284-95.PMID: 4306517

31. Schnurrenberger PR, Woods GT, Martin RJ. Serologic evidence of human infection with swine influenza virus.Am Rev Respir Dis. 1970;102(3):356-61.PMID: 5465431

32. Cuneo-Crovari P, Gasparini R, Pellegrino C. Seroepidemiological survey on human and swine influenza $A$. Situation at the onset of summer 1976.Boll Ist Sieroter Milan. 1976;55(5):463-70.PMID: 189788

33. Masurel N. Swine influenza virus and the recycling of influenza-A viruses in man.Lancet. 1976;2(7979):244-7. DOI: 10.1016/S0140-6736(76)91038-2 PMID: 59252

34. Pyhälä R. Antibodies to influenza A/swine-like viruses (Hsw1N1) in human sera: antigenic stimulation and changes in antibody status. Acta Pathol Microbiol Scand B. 1976;84B(6):373-8.PMID: 998257

35. Smith JW. Letter: Swine influenza in Hodgkin's disease.N Engl J Med. 1976;295(13):732. DOI: 10.1056/NEJM197609232951315 PMID: 958251

36. Thompson RL, Sande MA, Wenzel RP, Hoke CH, Gwaltney JM. Swine-influenza infection in civilians. Report of two cases.N Engl J Med. 1976;295(13):714-5. DOI: 10.1056/ NEJM197609232951307 PMID: 958246

37. Gaydos JC, Hodder RA, Top FH, Soden VJ, Allen RG, Bartley JD, et al. Swine influenza A at Fort Dix, New Jersey (JanuaryFebruary 1976). I. Case finding and clinical study of cases. J Infect Dis. 1977;136(Suppl):S356-62. DOI: 10.1093/infdis/136. Supplement_3.S356 PMID: 606759

38. Hodder RA, Gaydos JC, Allen RG, Top FH, Nowosiwsky T, Russell PK. Swine influenza A at Fort Dix, New Jersey (January-February 1976). III. Extent of spread and duration of the outbreak.J Infect Dis. 1977;136(Suppl):S369-75. DOI: 10.1093/infdis/136. Supplement_3.S369 PMID: 606761

39. O’Brien RJ, Noble GR, Easterday BC, Kendal AP, Shasby DM, Nelson DB, et al. Swine-like influenza virus infection in a Wisconsin farm family. J Infect Dis. 1977;136(Suppl):S390-6. DOI: 10.1093/infdis/136.Supplement_3.S390 PMID: 564374

40. Olson JG. Epizootic swine influenza with evidence of a low rate of human infection associated with occupational exposure to swine.Southeast Asian J Trop Med Public Health. 1977;8(3):368-70.PMID: 204060

41. Măgureanu E, Busuioc C, Ionescu V, Tisu A, Stoicescu A, Guguianu $E$, et al. Investigations on the involvement of swine 
influenza $A$ virus (Hsw1N1) in the influenza outbreak recorded in a town of Romania during the 1976--1977 winter season. Virologie. 1978;29(3):199-202.PMID: 567886

42. Tan DS, Omar M, Yap TC. Influenza HI antibodies in pig and man in Malaysia (with special reference to swine influenza). Med J Malaysia. 1979;34(2):159-62.PMID: 548720

43. Woods GT, Schnurrenberger PR, Martin RJ, Tompkins WA. Swine influenza virus in swine and man in Illinois.J Occup Med. 1981;23(4):263-7.PMID: 6260919

44. Sinnecker H, Sinnecker R, Zilske E, Strey A, Leopoldt D. Influenza virus $A$ /swine-outbreaks in domestic pigs and antibody findings in human sera.Zentralbl Bakteriol Mikrobiol Hyg A. 1983;255(2-3):209-13.PMID: 6316691

45. Profeta ML, Palladino G. Serological evidence of human infections with avian influenza viruses. Brief report.Arch Virol. 1986;90(3-4):355-60. DOI: 10.1007/BF01317384 PMID: 3729733

46. Wells DL, Hopfensperger DJ, Arden NH, Harmon MW, Davis $J P$, Tipple MA, et al. Swine influenza virus infections. Transmission from ill pigs to humans at a Wisconsin agricultural fair and subsequent probable person-to-person transmission. JAMA. 1991;265(4):478-81. DOI: 10.1001/ jama.1991.03460040054028 PMID: 1845913

47. Shortridge KF. Pandemic influenza: a zoonosis?Semin Respir Infect. 1992;7(1):11-25.PMID: 1609163

48. Shu LL, Zhou NN, Sharp GB, He SQ, Zhang TJ, Zou WW, et al. An epidemiological study of influenza viruses among Chinese farm families with household ducks and pigs. Epidemiol Infect. 1996;117(1):179-88. DOI: 10.1017/S0950268800001291 PMID: 8760967

49. Zhou N, He S, Zhang T, Zou W, Shu L, Sharp GB, et al. Influenza infection in humans and pigs in southeastern China. Arch Virol. 1996;141(3-4):649-61. DOI: 10.1007/BF01718323 PMID: 8645101

50. Peiris M, Yuen KY, Leung CW, Chan KH, Ip PL, Lai RW, et al. Human infection with influenza HoN2. Lancet. 1999;354(9182):916-7. DOI: 10.1016/S0140-6736(99)03311-5 PMID: 10489954

51. Mayahi M. Detection of Antibody Against Influenza A Subtype $\mathrm{H}_{9} \mathrm{~N}_{2}$ in Human Sera in Iran. The 11th International Symposium Of the World Association of Veterinary Laboratory Diagnosticians and OIE Seminar on Biotechnology; Ahvaz, Iran; 2003.

52. Ayora-Talavera G, Cadavieco-Burgos JM, Canul-Armas AB. Serologic evidence of human and swine influenza in Mayan persons.Emerg Infect Dis. 2005;11(1):158-61. DOI: 10.3201/ eid1101.040554 PMID: 15705345

53. Puzelli S, Di Trani L, Fabiani C, Campitelli L, De Marco MA, Capua I, et al. Serological analysis of serum samples from humans exposed to avian $\mathrm{H} 7$ influenza viruses in Italy between 1999 and 2003. J Infect Dis. 2005;192(8):1318-22. DOI: 10.1086/444390 PMID: 16170747

54. Barbour EK, Sagherian VK, Sagherian NK, Dankar SK, Jaber LS, Usayran NN, et al. Avian influenza outbreak in poultry in the Lebanon and transmission to neighbouring farmers and swine. Vet Ital. 2006;42(2):77-85.PMID: 20429054

55. Gill JS, Webby R, Gilchrist MJ, Gray GC. Avian influenza among waterfowl hunters and wildlife professionals.Emerg Infect Dis. 2006;12(8):1284-6. DOI: 10.3201/eid1708.060492 PMID: 16965717

56. Myers KP, Olsen CW, Setterquist SF, Capuano AW, Donham $\mathrm{KJ}$, Thacker EL, et al. Are swine workers in the United States at increased risk of infection with zoonotic influenza virus? Clin Infect Dis. 2006;42(1):14-20. DOI: 10.1086/498977 PMID: 16323086

57. Ramirez A, Capuano AW, Wellman DA, Lesher KA, Setterquist SF, Gray GC. Preventing zoonotic influenza virus infection. Emerg Infect Dis. 2006;12(6):996-1000. DOI: 10.3201/ eid1206.051576 PMID: 16707061

58. Gray GC, McCarthy T, Capuano AW, Setterquist SF, Olsen CW, Alavanja MC, et al. Swine workers and swine influenza virus infections. Emerg Infect Dis. 2007;13(12):1871-8. DOI: 10.3201/ eid1312.061323 PMID: 18258038

59. Myers KP, Setterquist SF, Capuano AW, Gray GC. Infection due to 3 avian influenza subtypes in United States veterinarians. Clin Infect Dis. 2007;45(1):4-9. DOI: $10.1086 / 518579$ PMID: 17554693

6o. Ortiz EJ, Kochel TJ, Capuano AW, Setterquist SF, Gray GC. Avian influenza and poultry workers, Peru, 2006.Influenza Other Respi Viruses. 2007;1(2):65-9. DOI: 10.1111/j.17502659.2007.00009.x PMID: 18167521

61. Robinson JL, Lee BE, Patel J, Bastien N, Grimsrud K, Seal $\mathrm{RF}$, et al. Swine influenza $\left(\mathrm{H}_{3} \mathrm{~N}_{2}\right)$ infection in a child and possible community transmission, Canada. Emerg Infect Dis. 2007;13(12):1865-70. DOI: 10.3201/eid1312.070615 PMID: 18258037
62. Skowronski DM, Li Y, Tweed SA, Tam TW, Petric M, David ST, et al. Protective measures and human antibody response during an avian influenza $\mathrm{H}_{7} \mathrm{~N}_{3}$ outbreak in poultry in British Columbia, Canada. CMAJ. 2007;176(1):47-53. DOI: 10.1503/ cmaj.060204 PMID: 17200390

63. Gray GC, McCarthy T, Capuano AW, Setterquist SF, Alavanja MC, Lynch CF. Evidence for avian influenza A infections among lowa's agricultural workers.Influenza Other Respi Viruses. 2008;2(2):61-9. DOI: 10.1111/j.1750-2659.2008.00041.x PMID: 18941621

64. Lu CY, Lu JH, Chen WQ, Jiang LF, Tan BY, Ling WH, et al. Potential infections of $\mathrm{H}_{5} \mathrm{~N}_{1}$ and $\mathrm{H}_{9} \mathrm{~N}_{2}$ avian influenza do exist in Guangdong populations of China. Chin Med J (Engl). 2008;121(20):2050-3.PMID: 19080274

65. Ogata T, Yamazaki Y, Okabe N, Nakamura Y, Tashiro M, Nagata $\mathrm{N}$, et al. Human $\mathrm{H}_{5} \mathrm{~N}_{2}$ avian influenza infection in Japan and the factors associated with high $\mathrm{H}_{5} \mathrm{~N}_{2}$-neutralizing antibody titer. J Epidemiol. 2008;18(4):160-6. DOI: 10.2188/jea. JE2007446 PMID: 18603824

66. Alizadeh EHS, Kheiri MT, Mazaheri V, Bashar R, Tabatabaeian M. Avian Influenza ( $\left.\mathrm{H}_{9} \mathrm{~N}_{2}\right)$ among poultry workers in Iran.Iran J Microbiol. 2009;1(3):3-6.

67. Jia N, de Vlas SJ, Liu YX, Zhang JS, Zhan L, Dang RL, et al. Serological reports of human infections of $\mathrm{H}_{7}$ and $\mathrm{H} 9$ avian influenza viruses in northern China. J Clin Virol. 2009;44(3):225-9. DOI: 10.1016/j.jcv.2008.12.014 PMID: 19186101

68. Wang M, Fu CX, Zheng BJ. Antibodies against $\mathrm{H}_{5}$ and $\mathrm{H}_{9}$ avian influenza among poultry workers in China.N Engl J Med. 2009;360(24):2583-4. DOI: 10.1056/NEJMC0900358 PMID: 19516044

69. Yamazaki Y, Doy M, Okabe N, Yasui Y, Nakashima K, Fujieda T, et al. Serological survey of avian $\mathrm{H}_{5} \mathrm{~N}_{2}$-subtype influenza virus infections in human populations. Arch Virol. 2009;154(3):421-7. DOI: 10.1007/s00705-009-0319-7 PMID: 19189196

70. Hadipour M. HoN2 Avian Influenza Virus Antibody Titres in Human Population in Fars Province, Iran.Brazilian Journal of Poultry Science.2010;12(3):161-4.

71. Kayali G, Ortiz EJ, Chorazy ML, Gray GC. Evidence of previous avian influenza infection among US turkey workers.Zoonoses Public Health. 2010;57(4):265-72. DOI: 10.1111/j.18632378.2009.01231.x PMID: 19486492

72. Krumbholz A, Lange J, Dürrwald R, Hoyer H, Bengsch S, Wutzler $P$, et al. Prevalence of antibodies to swine influenza viruses in humans with occupational exposure to pigs, Thuringia, Germany, 2008-2009. J Med Virol. 2010;82(9):161725. DOI: 10.1002/jmv.21869 PMID: 20648619

73. Qin PZ, Ming W, Liu Y, editors. Surveillance of human infections with Avian influenza in Guangzhou during 1997-2006. 14th International Congress on Infectious Diseases (ICID); 2010 Mar 9-12; Miami (FL, United States). Brookline (MA, United States): International Society for Infectious Diseases. Abstracts; 2010.

74. Terebuh P, Olsen CW, Wright J, Klimov A, Karasin A, Todd $\mathrm{K}$, et al. Transmission of influenza A viruses between pigs and people, lowa, 2002-2004. Influenza Other Respi Viruses. 2010;4(6):387-96. DOI: 10.1111/j.1750-2659.2010.00175.x PMID: 20958933

75. Dawood FS, Dong L, Liu F, Blau DM, Peebles PJ, Lu X, et al. A pre-pandemic outbreak of triple-reassortant swine influenza virus infection among university students, South Dakota, 2008. J Infect Dis. 2011;204(8):1165-71. DOI: 10.1093/infdis/ jir502 PMID: 21917888

76. Donahue JG, Coleman LA, Bender J, Kempf D, Vandermause MF, McGraw PJ, et al. Prospective study of avian influenza infection in backyard poultry flocks and flock handlers in Wisconsin. Vector Borne Zoonotic Dis. 2011;11(9):1293-7. DOI: 10.1089/vbz.2010.0260 PMID: 21612537

77. Gerloff NA, Kremer JR, Charpentier E, Sausy A, Olinger CM, Weicherding $P$, et al. Swine influenza virus antibodies in humans, western Europe, 2009. Emerg Infect Dis. 2011;17(3):403-11. DOI: 10.3201/eid1703.100851 PMID: 21392430

78. Gray GC, Ferguson DD, Lowther PE, Heil GL, Friary JA. A national study of US bird banders for evidence of avian influenza virus infections.J Clin Virol. 2011;51(2):132-5. DOI: 10.1016/j.jcv.2011.03.011 PMID: 21530384

79. Hadipour M. Seroprevalence of $\mathrm{H}_{9} \mathrm{~N}_{2}$ Avian Influenza Virus in Human Population in Boushehr Province, Iran.Asian J Anim Vet Adv. 2011;6(2):196-200 .DOI: 10.3923/ajava.2011.196.200

8o. Kayali G, Barbour E, Dbaibo G, Tabet C, Saade M, Shaib HA, et al. Evidence of infection with $\mathrm{H}_{4}$ and $\mathrm{H}_{11}$ avian influenza viruses among Lebanese chicken growers. PLoS One. 2011;6(10):e26818. DOI: 10.1371/journal.pone.0026818 PMID: 22046370 
81. Khuntirat BP, Yoon IK, Blair PJ, Krueger WS, Chittaganpitch M, Putnam SD, et al. Evidence for subclinical avian influenza virus infections among rural Thai villagers. Clin Infect Dis. 2011;53(8):e107-16. DOI: 10.1093/cid/cir525 PMID: 21921216

82. Kitikoon P, Sreta D, Tuanudom R, Amonsin A, Suradhat $\mathrm{S}$, Oraveerakul K, et al. Serological evidence of pigto-human influenza virus transmission on Thai swine farms. Vet Microbiol. 2011;148(2-4):413-8. DOI: 10.1016/j. vetmic.2010.09.019 PMID: 20965670

83. Kohls A, Hafez HM, Harder T, Jansen A, Lierz P, Lüschow D, et al. Avian influenza virus risk assessment in falconry. Virol J. 2011;8(1):187. DOI: 10.1186/1743-422X-8-187 PMID: 21513552

84. Leibler JH, Silbergeld EK, Pekosz A, Gray GC. No evidence of infection with avian influenza viruses among US poultry workers in the Delmarva Peninsula, Maryland and Virginia, USA.J Agromed. 2011;16(1):52-7. DOI: 10.1080/1059924X.2011.533612 PMID: 21213164

85. Shtjefni V, Kumbe I, , Cabeli P, Shoshi N, Atipi I, Shtylla T. Serologic evidence of $\mathrm{H}_{1} \mathrm{~N}_{1}$ and $\mathrm{H}_{3} \mathrm{~N}_{2}$ swine influenza virus in swine workers.CR Acad Bulg sci. 2011;64(11):1549-54.

86. Arzey GG, Kirkland PD, Arzey KE, Frost M, Maywood P, Conaty $\mathrm{S}$, et al. Influenza virus $A\left(\mathrm{H}_{10} \mathrm{~N} 7\right)$ in chickens and poultry abattoir workers, Australia. Emerg Infect Dis. 2012;18(5):814-6. DOI: 10.3201/eid1805.111852 PMID: 22516302

87. Di Trani L, Porru S, Bonfanti L, Cordioli P, Cesana BM, Boni A, et al. Serosurvey against $\mathrm{H}_{5}$ and $\mathrm{H}_{7}$ avian influenza viruses in Italian poultry workers. Avian Dis. 2012;56(4) Suppl;1068-71. DOI: 10.1637/10184-041012-ResNote.1 PMID: 23402138

88. López-Robles G, Montalvo-Corral M, Caire-Juvera G, AyoraTalavera G, Hernández J. Seroprevalence and risk factors for swine influenza zoonotic transmission in swine workers from northwestern Mexico.Transbound Emerg Dis. 2012;59(2):183-8. DOI: 10.1111/j.1865-1682.2011.01250.x PMID: 21801341

89. Pawar SD, Tandale BV, Raut CG, Parkhi SS, Barde TD, Gurav YK, et al. Avian influenza $\mathrm{H}_{9} \mathrm{~N} 2$ seroprevalence among poultry workers in Pune, India, 2010. PLoS One. 2012;7(5):e36374. DOI: 10.1371/journal.pone.0036374 PMID: 22623954

90. Shafir SC, Fuller T, Smith TB, Rimoin AW. A national study of individuals who handle migratory birds for evidence of avian and swine-origin influenza virus infections.J Clin Virol. 2012;54(4):364-7. DOI: 10.1016/j.jcv.2012.05.001 PMID: 22632900

91. Uyeki TM, Nguyen DC, Rowe T, Lu X, Hu-Primmer J, Huynh $L P$, et al. Seroprevalence of antibodies to avian influenza A $\left(\mathrm{H}_{5}\right)$ and $\mathrm{A}\left(\mathrm{H}_{9}\right)$ viruses among market poultry workers, Hanoi, Vietnam, 2001. PLoS One. 2012;7(8):e43948. DOI: 10.1371/ journal.pone.0043948 PMID: 22928049

92. Wong KK, Greenbaum A, Moll ME, Lando J, Moore EL, Ganatra $R$, et al. Outbreak of influenza $A\left(\mathrm{H}_{3} \mathrm{~N}_{2}\right)$ variant virus infection among attendees of an agricultural fair, Pennsylvania, USA, 2011. Emerg Infect Dis. 2012;18(12):1937-44. DOI: 10.3201/ eid1812.121097 PMID: 23171635

93. Yang P, Ma C, Shi W, Cui S, Lu G, Peng X, et al. A serological survey of antibodies to $\mathrm{H}_{5}, \mathrm{H}_{7}$ and $\mathrm{H}_{9}$ avian influenza viruses amongst the duck-related workers in Beijing, China. PLoS One. 2012;7(11):e50770. DOI: 10.1371/journal.pone.0050770 PMID: 23226380

94. Yang P, Shi W, Cui S, Zhang Y, Liu X, Wang Q. Infection with multiple avian influenza viruses in a man without poultryhandling practices suggesting an increased probability of emergent pandemic influenza virus in general population. Clin Infect Dis. 2012;54(2):307. DOI: 10.1093/cid/cir844 PMID: 22144542

95. Luetteke N, Gerloff NA, Gohrbandt S, Weicherding P, van Reeth K, Muller CP. Neutralizing antibodies against pandemic, seasonal and avian-like $\mathrm{H}_{1} \mathrm{~N}_{1}$ swine influenza virus in swine contacts and swine, Western-Europe.Int J Infect Dis. 2012;16(Suppl 1):e136 .DOI: 10.1016/j.ijid.2012.05.308 PMID: 22197748

96. Ahad A, Rabbani M, Yaqub T, Younus M, Mahmood A, Shabbir $M Z$, et al. Serosurveillance to $\mathrm{H}_{9}$ and $\mathrm{H}_{7}$ Avian Influenza Virus among Poultry Workers in Punjab Province, Pakistan. Pak Vet J. 2012;33(1):107-12.

97. Bai T, Zhou J, Shu Y. Serologic study for influenza A $(\mathrm{H} 7 \mathrm{Ng})$ among high-risk groups in China.N Engl J Med. 2013;368(24):2339-40. DOI: 10.1056/NEJMC1305865 PMID: 23718151

98. Blair PJ, Putnam SD, Krueger WS, Chum C, Wierzba TF, Heil $\mathrm{GL}$, et al. Evidence for avian $\mathrm{H}_{9} \mathrm{~N}_{2}$ influenza virus infections among rural villagers in Cambodia. J Infect Public Health. 2013;6(2):69-79. DOI: 10.1016/j.jiph.2012.11.005 PMID: 23537819

99. Huang R, Wang AR, Liu ZH, Liang W, Li XX, Tang YJ, et al. Seroprevalence of avian influenza H9N2 among poultry workers in Shandong Province, China. Eur J Clin Microbio
Infect Dis. 2013;32(10):1347-51. DOI: 10.1007/s10096-013-18887 PMID: 23733318

100. Khurelbaatar N, Krueger WS, Heil GL, Darmaa B, Ulziimaa D, Tserennorov D, et al. Sparse evidence for equine or avian influenza virus infections among Mongolian adults with animal exposures. Influenza Other Respi Viruses. 2013;7(6):1246-50. DOI: 10.1111/irv.12148 PMID: 23941547

101. Krueger WS, Khuntirat B, Yoon IK, Blair PJ, Chittagarnpitch $M$, Putnam SD, et al. Prospective study of avian influenza virus infections among rural Thai villagers. PLoS One. 2013;8(8):e72196. DOI: 10.1371/journal.pone.0072196 PMID: 23977250

102. Okoye J, Eze D, Krueger WS, Heil GL, Friary JA, Gray GC. Serologic evidence of avian influenza virus infections among Nigerian agricultural workers.J Med Virol. 2013;85(4):670-6. DOI: $10.1002 /$ jmv.23520 PMID: 23400898

103. Su S, Chen J, Cao Z, Lai A, Gu H, Ke C, et al. Detection of antibodies against Avian influenza virus subtypes $\mathrm{H}_{7}$ and $\mathrm{H} 9$ among veterinarians in Guangdong province, China. J Clin Microbiol. 2013;51(12):4272-4. DOI: 10.1128/JCM.01812-13 PMID: 24048542

104. Yu Q, Liu L, Pu J, Zhao J, Sun Y, Shen G, et al. Risk perceptions for avian influenza virus infection among poultry workers, China. Emerg Infect Dis. 2013;19(2):313-6. DOI: 10.3201/eid1902.120251 PMID: 23343592

105. Zu R, Dong L, Qi X, Wang D, Zou S, Bai T, et al. Virological and serological study of human infection with swine influenza $A \mathrm{H}_{1} \mathrm{~N}_{1}$ virus in China. Virology. 2013;446(1-2):4955. DOI: 10.1016/j.virol.2013.07.022 PMID: 24074566

106. Krueger WS, Heil GL, Yoon KJ, Gray GC. No evidence for zoonotic transmission of $\mathrm{H}_{3} \mathrm{~N} 8$ canine influenza virus among US adults occupationally exposed to dogs.Influenza Other Respi Viruses. 2014;8(1):99-106. DOI: 10.1111/irv.12208 PMID: 24237615

107. Anvar E, Hosseini SM, Tavasoti Kheiri M, Mazaheri V, Fazaei K, Shabani M, et al. Serological Survey of Avian Influenza (HoN2) Among Different Occupational Groups in Tehran and Qazvin Provinces in IR Iran. Jundishapur J Microbiol. 2013;6(4):e5441.

108. Khurelbaatar N, Krueger WS, Heil GL, Darmaa B, Ulziimaa $D$, Tserennorov D, et al. Little evidence of avian or equine influenza virus infection among a cohort of Mongolian adults with animal exposures, 2010-2011. PLoS One. 2014;9(1):e85616. DOI: 10.1371/journal.pone.0085616 PMID: 24465622

109. Krumbholz A, Lange J, Dürrwald R, Walther M, Müller TH, Kühnel D, et al. Prevalence of antibodies to European porcine influenza viruses in humans living in high pig density areas of Germany. Med Microbiol Immunol (Berl). 2014;203(1):13-24. DOI: 10.1007/s00430-013-0309-y PMID: 24013183

110. Yang S, Chen Y, Cui D, Yao H, Lou J, Huo Z, et al. Avianorigin influenza $A\left(\mathrm{H}_{7} \mathrm{~N} 9\right)$ infection in influenza $A\left(\mathrm{H}_{7} \mathrm{~N} 9\right)$ affected areas of China: a serological study. J Infect Dis. 2014;209(2):265-9. DOI: 10.1093/infdis/jit430 PMID: 23935201

111. Zhou P, Zhu W, Gu H, Fu X, Wang L, Zheng Y, et al. Avian influenza $\mathrm{H}_{9} \mathrm{~N} 2$ seroprevalence among swine farm residents in China. J Med Virol. 2014;86(4):597-600. DOI: 10.1002/ jmv.23869 PMID: 24390939

112. Qi W, Su S, Xiao C, Zhou P, Li H, Ke C, et al. Antibodies against $\mathrm{H} 10 \mathrm{~N} 8$ avian influenza virus among animal workers in Guangdong Province before November 30, 2013, when the first human $\mathrm{H}_{10} \mathrm{~N} 8$ case was recognized. BMC Med. 2014;12(1):205. DOI: 10.1186/S12916-014-0205-3 PMID: 25348464

113. Zhou H, Zheng Y, Wang L, Cui J, Fu X, He S, et al. First serologic study for influenza $\mathrm{A}\left(\mathrm{H}_{7} \mathrm{~N} 9\right)$ virus among veterinarians in Guangdong, China. J Clin Virol. 2014;60(2):182-3. DOI: 10.1016/j.jcv.2014.03.007 PMID 24717773

114. Pawar SD, Tandale BV, Gurav YK, Parkhi YK, Kode SS. Immunity status against influenza A subtype $\mathrm{H}_{7} \mathrm{~N} 9$ and other avian influenza viruses in a high-risk group and the general population in India.J Infect Dis. 2014;210(1):160-1. DOI: 10.1093/infdis/jiu033 PMID: 24453261

115. Yin X, Yin X, Rao B, Xie C, Zhang P, Qi X, et al. Antibodies against avian-like $A\left(\mathrm{H}_{1} \mathrm{~N}_{1}\right)$ swine influenza virus among swine farm residents in eastern China. J Med Virol. 2014;86(4):592-6. DOI: 10.1002/jmv.23842 PMID: 24497077

116. Zhou H, Cao Z, Tan L, Fu X, Lu G, Qi W, et al. Avian-like $A\left(\mathrm{H}_{1} \mathrm{~N}_{1}\right)$ swine influenza virus antibodies among swine farm residents and pigs in southern China. Jpn J Infect Dis. 2014;67(3):184-90. DOI: 10.7883/yoken.67.184 PMID: 24858607 
117. Coman A, Maftei DN, Krueger WS, Heil GL, Chereches RM, Sirlincan E, et al. A prospective study of Romanian agriculture workers for zoonotic influenza infections. PLoS One. 2014;9(5):eg8248. DOI: 10.1371/journal.pone.0098248 PMID: 24869796

118. Gray GC, Krueger WS, Chum C, Putnam SD, Wierzba TF, Heil $\mathrm{GL}$, et al. Little evidence of subclinical avian influenza virus infections among rural villagers in Cambodia. PLoS One. 2014;9(5):e97097. DOI: 10.1371/journal.pone.0097097 PMID: 24819948

119. Wang Q, Ju L, Liu P, Zhou J, Lv X, Li L, et al. Serological and virological surveillance of avian influenza $A$ virus $\mathrm{H}_{9} \mathrm{~N}_{2}$ subtype in humans and poultry in Shanghai, China, between 2008 and 2010. Zoonoses Public Health. 2015;62(2):131-40. DOI: $10.1111 /$ zph.12133 PMID: 24803167

120. Shamliyan T, Kane RL, Dickinson S. A systematic review of tools used to assess the quality of observational studies that examine incidence or prevalence and risk factors for diseases.J Clin Epidemiol. 2010;63(10):1061-70. DOI: 10.1016/j.jclinepi.2010.04.014 PMID: 20728045

121. Wood JM, Montomoli E, Newman RW, Daas A, Buchheit KH, Terao E. Collaborative study on influenza vaccine clinical trial serology - part 2: reproducibility study.Pharmeur Bio Sci Notes. 2011;2011(1):36-54.PMID: 21619855

122. Stephenson I, Heath A, Major D, Newman RW, Hoschler $\mathrm{K}$, Junzi W, et al. Reproducibility of serologic assays for influenza virus A (H5N1). Emerg Infect Dis. 2009;15(8):12529. DOI: 10.3201/eid1508.081754 PMID: 19751587

123. Wagner R, Pfleiderer M. Reproducibility of assays for influenza vaccine immunogenicity determination: progress towards consistency. Expert Rev Vaccines. 2012;11(8):881-3. DOI: 10.1586/erv.12.62 PMID: 23002967

124. Wagner R, Göpfert C, Hammann J, Neumann B, Wood J, Newman R, et al. Enhancing the reproducibility of serological methods used to evaluate immunogenicity of pandemic $\mathrm{H}_{1} \mathrm{~N}_{1}$ influenza vaccines-an effective EU regulatory approach. Vaccine. 2012;30(27):4113-22. DOI: 10.1016/j. vaccine.2012.02.077 PMID: 22446639

125. Buchy P, Vong S, Chu S, Garcia JM, Hien TT, Hien VM, et al. Kinetics of neutralizing antibodies in patients naturally infected by $\mathrm{H}_{5} \mathrm{~N}_{1}$ virus. PLoS One. 2010;5(5):e10864. DOI: 10.1371/journal.pone.0010864 PMID: 20532246

126. WHO. Seroepidemiological studies of pandemic influenza $A$ (H1N1) 2009 virus.Wkly Epidemiol Rec. 2010;85(24):229-35. PMID: 20545056

127. Laurie KL, Huston P, Riley S, Katz JM, Willison DJ, Tam IS, et al. Influenza serological studies to inform public health action: best practices to optimise timing, quality and reporting. Influenza Other Respi Viruses. 2013;7(2):211-24. DOI: 10.1111/j.1750-2659.2012.0370a.x PMID: 22548725

128. Nelson MI, Vincent AL. Reverse zoonosis of influenza to swine: new perspectives on the human-animal interface. Trends Microbiol. 2015;23(3):142-53. DOI: 10.1016/j. tim.2014.12.002 PMID: 25564096

129. Van Kerkhove MD, Broberg E, Engelhardt OG, Wood J, Nicoll A, CONSISE steering committee. The consortium for the standardization of influenza seroepidemiology (CONSISE): a global partnership to standardize influenza seroepidemiology and develop influenza investigation protocols to inform public health policy.Influenza Other Respi Viruses. 2013;7(3):231-4. DOI: 10.1111/irv.12068 PMID: 23280042

130. De Marco MA, Porru S, Cordioli P, Cesana BM, Moreno A, Calzoletti $L$, et al. Evidence of cross-reactive immunity to 2009 pandemic influenza A virus in workers seropositive to swine $\mathrm{H}_{1} \mathrm{~N}_{1}$ influenza viruses circulating in Italy. PLoS One. 2013;8(2):e57576. DOI: 10.1371/journal.pone.0057576 PMID: 23469029

131. Wu J, Yi L, Ni H, Zou L, Zhang H, Zeng X, et al. Anti-Human $\mathrm{H}_{1} \mathrm{~N}_{1}$ dmog and swine $\mathrm{H}_{1} \mathrm{~N}_{1}$ Virus Antibodies among Swine Workers in Guangdong Province, China. Sci Rep. 2015;5:12507. DOI: 10.1038/srep12507 PMID: 26205221

132. Vincent A, Awada L, Brown I, Chen H, Claes F, Dauphin $G$, et al. Review of influenza $A$ virus in swine worldwide: a call for increased surveillance and research. Zoonoses Public Health. 2014;61(1):4-17. DOI: 10.1111/zph.12049 PMID: 23556412

133. World Health Organization (WHO). Influenza at the humananimal interface. Summary and assessment, 20 July to 3 October 2016. Geneva: WHO. Available from: http://www. who.int/influenza/human_animal_interface/Influenza_ Summary_IRA_HA_interface_10_03_2016.pdf?ua=1

134. Butt KM, Smith GJ, Chen H, Zhang LJ, Leung YH, Xu KM, et al. Human infection with an avian $\mathrm{H}_{9} \mathrm{~N}_{2}$ influenza $\mathrm{A}$ virus in Hong Kong in 2003. J Clin Microbiol. 2005;43(11):5760-7. DOI: 10.1128/JCM.43.11.5760-5767.2005 PMID: 16272514
135. Huang Y, Li X, Zhang H, Chen B, Jiang Y, Yang L, et al. Human infection with an avian influenza $\mathrm{A}\left(\mathrm{H}_{9} \mathrm{~N}_{2}\right)$ virus in the middle region of China. J Med Virol. 2015;87(10):1641-8. DOI: 10.1002/jmv.24231 PMID: 25965534

136. Xu KM, Smith GJ, Bahl J, Duan L, Tai H, Vijaykrishna D, et al. The genesis and evolution of $\mathrm{H}_{9} \mathrm{~N}_{2}$ influenza viruses in poultry from southern China, 2000 to 2005 . J Virol. 2007;81(19):10389-401. DOI: 10.1128/JVI.00979-07 PMID: 17652402

137. Zhu Y, Yang Y, Liu W, Liu X, Yang D, Sun Z, et al. Comparison of biological characteristics of $\mathrm{H}_{9} \mathrm{~N} 2$ avian influenza viruses isolated from different hosts. Arch Virol. 2015;160(4):917-27. DOI: 10.1007/s00705-015-2337-y PMID: 25616845

138. Cong YL, Pu J, Liu QF, Wang S, Zhang GZ, Zhang XL, et al. Antigenic and genetic characterization of $\mathrm{H}_{9} \mathrm{~N}_{2}$ swine influenza viruses in China. J Gen Virol. 2007;88(Pt 7):203541. DOI: 10.1099/vir.0.82783-0 PMID: 17554038

139. Sun X, Xu X, Liu Q, Liang D, Li C, He Q, et al. Evidence of avian-like $\mathrm{H}_{9} \mathrm{~N} 2$ influenza A virus among dogs in Guangxi, China. Infect Genet Evol. 2013;20:471-5. DOI: 10.1016/j. meegid.2013.10.012 PMID: 24161411

140. Chen H, Yuan H, Gao R, Zhang J, Wang D, Xiong Y, et al. Clinical and epidemiological characteristics of a fatal case of avian influenza A H1oN8 virus infection: a descriptive study. Lancet. 2014;383(9918):714-21. DOI: 10.1016/S01406736(14)60111-2 PMID: 24507376

141. Gao R, Cao B, Hu Y, Feng Z, Wang D, Hu W, et al. Human infection with a novel avian-origin influenza A ( $\left.\mathrm{H}_{7} \mathrm{N9}\right)$ virus. N Engl J Med. 2013;368(20):1888-97. DOI: 10.1056/ NEJMoa1304459 PMID: 23577628

142. Guan Y, Shortridge KF, Krauss S, Webster RG. Molecular characterization of $\mathrm{H}_{9} \mathrm{~N} 2$ influenza viruses: were they the donors of the "internal" genes of $\mathrm{H}_{5} \mathrm{~N}_{1}$ viruses in Hong Kong?Proc Natl Acad Sci USA. 1999;96(16):9363-7. DOI: 10.1073/pnas.96.16.9363 PMID: 10430948

143. Wei SH, Yang JR, Wu HS, Chang MC, Lin JS, Lin CY, et al. Human infection with avian influenza A H6N1 virus: an epidemiological analysis. Lancet Respir Med. 2013;1(10):7718. DOI: 10.1016/S2213-2600(13)70221-2 PMID: 24461756

144. Pepin KM, Wang J, Webb CT, Smith GJ, Poss M, Hudson PJ, et al. Multiannual patterns of influenza A transmission in Chinese live bird market systems. Influenza Other Respi Viruses. 2013;7(1):97-107. DOI: 10.1111/j.17502659.2012.00354.x PMID: 22458429

145. Jiao P, Cao L, Yuan R, Wei L, Song Y, Shen D, et al. Complete genome sequence of an $\mathrm{H}_{10 \mathrm{~N} 8}$ avian influenza virus isolated from a live bird market in Southern China. Virol. 2012;86(14):7716. DOI: 10.1128/JVI.00959-12 PMID: 22733881

146. Pavade G, Weber-Vintzel L, Hamilton K, Dehove A, Zepeda $C$. OFFLU review of avian influenza surveillance and epidemiological projects in some European, African, and Asian countries. OIE/FAO Network of Expertise on Animal Influenza (OFFLU). 2011:11.

147. Von Dobschuetz S, DE Nardi M, Harris KA, Munoz O, Breed AC, Wieland B, et al. , FLURISK Consortium. Influenza surveillance in animals: what is our capacity to detect emerging influenza viruses with zoonotic potential?Epidemiol Infect. 2015;143(10):2187-204. DOI: 10.1017/So950268814002106 PMID: 25268692

\section{License and copyright}

This is an open-access article distributed under the terms of the Creative Commons Attribution (CC BY 4.0) Licence. You may share and adapt the material, but must give appropriate credit to the source, provide a link to the licence, and indicate if changes were made.

This article is copyright of the authors, 2016. 